\title{
Glazy narzutowe z okolic Przedborza jako obiekty geodziedzictwa oraz ich znaczenie dla geologii czwartorzędu i geoturystyki
}

\author{
Maria Górska-Zabielska $^{1}$, Dariusz Wieczorek ${ }^{2}$, Ryszard Zabielski $^{3}$, Andrzej Stoiński ${ }^{2}$
}
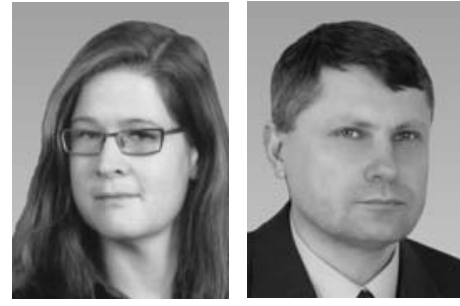

M. Górska-Zabielska

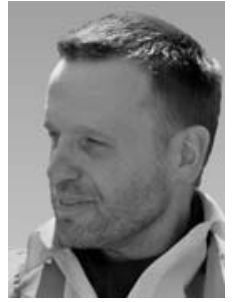

R. Zabielski

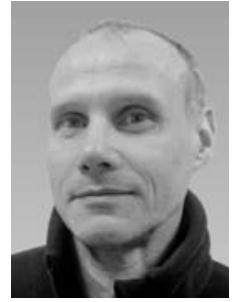

A. Stoiński

Erratic boulders from the Przedbórz Region as objects important for Quaternary geology and geoheritage. Prz. Geol., 70: 34-49; doi: 10.7306/2022.2

A b stra ct. The Przedbórz region in the Przedborska Upland (central Poland) is characterized by an above-average presence of erratic boulders. They have never been the subject of separate studies before. The aim of this article is to indicate their large population in central Poland and to characterize the traces of the impact of various morphogenetic processes on their current size and shape. The authors indicate the Scandinavian source areas of some of the studied erratic boulders. The article also highlights the scientific, educational, social and aesthetic function of erratic boulders, which should be used when planning the sustainable development of the region. In peripheral tourist areas, geotourism is an effective tool for economic growth. The erratic boulders discussed in the article, which are unique objects of natural heritage, have great potential to revive this branch of nature tourism.

Keywords: erratic boulders, indicator erratics, Scandinavian source regions, geotourism, sustainable development, Przedbórz

Głazy narzutowe występujące na terenie Polski to porwaki skał pochodzące z tarczy skandynawskiej i obszaru dna Morza Bałtyckiego, które zostały przytransportowane i zdeponowane przez lądolody skandynawskie w czasie zlodowaceń plejstoceńskich. W literaturze trudno znaleźć jedną spójną informację o wymiarach narzutniaka, wg których byłyby one klasyfikowane jako głaz. Vinx (2015) pisze, że nie ma wymogu minimalnego rozmiaru. W powszechnym rozumieniu zakłada się minimalna średnicę nieco poniżej $1 \mathrm{~m}$. Schulz (2003) nie przytacza w ogóle wymiarów, które obiekt geologiczny musi mieć, by był zaliczony do frakcji głazowej. Według Wentwortha (1922) i Górskiej-Zabielskiej (2010) przyjmowano, że wymiar najkrótszej osi takiego obiektu nie powinien być mniejszy niż $0,256 \mathrm{~m}$. Ostatnio podaje się także wymiar 0,5 m (np. Górska-Zabielska i in., 2020).

Występujące na obszarze depozycji glacjalnej narzutniaki skandynawskie są reprezentowane przez wszystkie typy petrograficzne skał, chociaż dominują skały magmowe i metamorficzne. Znacząca przewaga ilościowa tych skał nad osadowymi wynika z budowy geologicznej obszaru źródłowego w Skandynawii (np. Lundquist, 1979; Ager, 1980; Gorbatschev, 1980, 1985; Gaál, Gorbatschev, 1987; Andréasson, Rodhe, 1990; Fredén, 1994; Lundquist, Bygghammar, 1994; Tuuling, Flodén, 2001; Cocks, Torsvik, 2005; Bogdanova i in., 2008; Hölltä i in., 2008; Wohlfarth i in., 2008) oraz ich większej odporności na niszczenie. Wśród dużych głazów narzutowych tylko 2\% stanowią skały osadowe (Schulz, 1996, 1999).

Głazy narzutowe należą do dziedzictwa geologicznego (Górska-Zabielska,2 015, 2020, 2021a, b), współtworząc jego georóżnorodność (np. Gray, 2004, 2005, 2013, 2018;
Serrano i in., 2007; Brilha i in., 2018; Coratza i in., 2018; Zwoliński i in., 2018; Wolniewicz, 2021), współcześnie są traktowane jako geostanowiska (Reynard, 2004; Migoń, 2012; Duraj i in., 2017; Migoń, Różycka, 2021), w których realizowany jest transfer wiedzy od eksperta, geointerpretatora do odbiorcy (np. Kubalikova i in., 2021). Dokumentują procesy geologiczne, jakie zachodziły w przeszłości na obszarze źródłowym (np. wietrzenie czy niszczące procesy subglacjalne: egzaracja, detersja i detrakcja) oraz z okresu, kiedy były transportowane w obrębie lądolodu na obszar depozycji glacjalnej (np. obróbka naroży czy detersja podłoża, po którym przemieszczał się lądolód). Na powierzchni głazu są również zapisane ślady oddziaływania rozmaitych procesów, np. peryglacjalnych, funkcjonujących w strefie ekstraglacjalnej. Jeśli głaz nie zmienił swej lokalizacji (poprzez czynnik antropogeniczny) od momentu depozycji (czyli występuje w pozycji in situ), ma przede wszystkim walor naukowy. Wykorzystuje się go wówczas w analizach statystycznych do określenia głównego kierunku transportu przez lądolód, jak również do datowania początku deglacjacji obszaru objętego zlodowaceniem z użyciem izotopów kosmogenicznych, np. ${ }^{10} \mathrm{Be}$ (m.in. Rinterknecht i in., 2005, 2012; Ivy-Ochs, Kober, 2008; Tylmann i in., 2017, 2019). Jeśli głaz narzutowy podlega ochronie prawnej, pełni rolę konserwatorską. Głaz dużych rozmiarów i odpowiednio wyeksponowany - może pełnić funkcję estetyczną (Kirillova i in., 2014; Kirillova, Lehto, 2015; Ruban i in., 2020). Zlokalizowany na szlaku turystycznym, opatrzony tablicą informacyjną, będzie miał walor edukacyjny (np. Wolniewicz, 2021) i nie mniej ważną - rolę rekreacyjną. Takie funkcje pełnią także głazy narzutowe, które dla ich zachowania, zostały przemieszczone

\footnotetext{
${ }^{1}$ Uniwersytet Jana Kochanowskiego, ul. Uniwersytecka 7, 25-406 Kielce; maria.gorska-zabielska@ujk.edu.pl

2 Państwowy Instytut Geologiczny - Państwowy Instytut Badawczy, Oddział Swiętokrzyski, ul. Zgoda 21, 25-378 Kielce; dariusz.wieczorek@pgi.gov.pl; andrzej.stoinski@pgi.gov.pl

${ }^{3}$ Państwowy Instytut Geologiczny - Państwowy Instytut Badawczy, ul. Rakowiecka 4, 00-975 Warszawa; ryszard.zabielski@pgi.gov.pl
} 
i zgromadzone np. w lapidariach (np. Meyer, 2006; Keiter, 2017; Górska-Zabielska, 2021a; http://www.sp6.pruszkow.pl/index.php?option=com_content\&task=view\&id=1406\&Itemid=30), gdzie dodatkowo pełnią funkcję społeczną poprzez uświadomienie odbiorcom, jak ważne dla prawidłowego funkcjonowania przyrody jest zachowanie i ochrona wszystkich jej elementów (Urban i in., 2021). Głazy narzutowe mają duży potencjał do rozwoju geoturystyki (m.in. Hose, 2005, 2012; Dowling, Newsome, 2005; Górska-Zabielska, Dobracki, 2015; Górska-Zabielska, Zabielski, 2018; Górska-Zabielska i in., 2019, 2020; Górska-Zabielska, 2020, 2021a). Jest to ciągle słabo rozwinięta w Polsce gałąź turystyki przyrodniczej, mającej na celu ochronę dziedzictwa geologicznego i geomorfologicznego poprzez efektywne zabezpieczenie geostanowisk, szeroka promocję nauk geologicznych oraz propagowanie ich funkcji edukacyjnych i turystycznych. Geoturystyka bezkonfliktowo wykorzystuje naturalne walory obszaru w lokalnej polityce zrównoważonego rozwoju społecznego i ekonomicznego (np. Brilha i in., 2018).

W trakcie badań terenowych towarzyszących aktualizacji ark. Przedbórz (775) Szczegółowej Mapy Geologicznej Polski w skali 1 : 50000 (SMGP), stwierdzono, że na tym obszarze występują liczne głazy narzutowe (Wieczorek i in., 2020a, b). Od czasów Sawickiego (1922) i Świdzińskiego (1935) nie były one przedmiotem bliższego, odrębnego zainteresowania. Jedynie Kwapisz (1983), opracowując arkusz Przedbórz (775), wskazał, że głazy granitowe, gnejsowe i piaskowcowe najczęściej występują w postaci czap głazowisk w stropie osadów budujących wzgórza moren czołowych. Dostrzegł on również większe ich nagromadzenie na wschód od Przedborza i w okolicy Sokolej Góry. Poza tymi wymienionymi, na obszarze arkusza Przedbórz, wg Kwapisza (1983) głazy narzutowe o średnicy nawet do 2,0 m sq rozrzucone nierównomiernie i nie tworza większych skupisk.

Głazy narzutowe na terenie całej Polski inwentaryzowała także Czernicka-Chodkowska (1977, 1980, 1983). Wykazała ona, że są one rozmieszczone w sposób rozproszony. Badania Czernickiej-Chodkowskiej (1983), Urbana (1990, 1997), Stoińskiego (1997), Pernala (2004, 2005), Górskiej-Zabielskiej (2019a, b) oraz Górskiej-Zabielskiej $\mathrm{i}$ in. $(2019,2020)$ wskazują na regiony zwiększonej obecności głazów narzutowych na granicy Wyżyn: Przedborskiej i Kieleckiej.

Celem niniejszego artykułu jest wskazanie częstszego występowania głazów narzutowych w strefie glacjomarginalnej MIS 6 (Marine Isotope Stage, morskie stadium tlenowe 6 = 130-190 ka BP) w środkowej Polsce w stosunku do regionów położonych na zapleczu i przedpolu tej strefy (np. Górska-Zabielska, 2019a, b; Górska-Zabielska i in., 2019; inf. ust. Zabielski, 2021). Ponadto autorzy chcą udokumentować, na wielu z nich, ślady oddziaływania zróżnicowanych procesów morfogenetycznych, a więc odtworzyć historię zapisana $w$ kamieniu. Nie mniej ważnym celem jest wskazanie skandynawskich obszarów źródłowych niektórych z badanych głazów narzutowych. Wiedza ta ma posłużyć do wykorzystania tych wyjątkowych obiektów dziedzictwa przyrodniczego w zrównoważonym rozwoju regionu, którego skutecznym narzędziem jest geoturystyka (np. Farsani i in., 2012).

Autorzy liczą, że artykuł zainteresuje swoją treścią tych czytelników, którzy pasjonują się geologią czy geografią, nauczycieli geografii lub geointerpretatorów, jak również inne osoby, które być może po raz pierwszy dostrzegą w głazach narzutowych interesujące obiekty, stanowiące elementy abiotycznej części ekosystemu (por. Urban i in., 2021).

\section{OBSZAR BADAŃ}

Obszar badań obejmuje powierzchnię arkusza Przedbórz (775) SMGP w skali 1 : 50 000, jest położony na Wyżynie Przedborskiej w granicach Wyżyny Małopolskiej. Badania prowadzono na pograniczu Wzgórz Radomszczańskich, Opoczyńskich i Łopuszańskich oraz Pasma Przedborsko-Małogoskiego. Przez obszar badań przepływa z południa na północ rzeka Pilica.

W okolicach Przedborza licznie występują wychodnie skał kredowych i jurajskich, a także niewielka wychodnia utworów triasowych (ryc. 1). Część z nich wyraźnie zaznacza się w morfologii. Od Przedborza w kierunku SE rozciagga się Pasmo Przedborsko-Małogoskie. Budują je piaskowce albu i wapienie kimerydu (Lewiński, 1908; Świdziński, 1935; Kutek, 1968; Kwapisz, 1983; Wieczorek i in., 2020a, b). Z uwagi na ich wykształcenie litologiczne oraz uwarunkowania strukturalne dają one rzeźbę kuestową lub odpornościową (por. Sala, 2011). Do Pasma Przedborsko-Małogoskiego przylega od strony zachodniej brachyantyklina Dobromierza (por. Świdziński, 1935; Passendorfer, 1939; Cieśliński, 1956; Wartołowska-Świdrowska, 1976), której występowanie jest uwarunkowane tektonicznie uskokiem Dobromierza. W środkowej części tej struktury występują wapienie kimerydu, a brzeżnej piaskowce albu. Na zachód od Przedborza znajduje się góra Chełmo. Jest ona wyniesionym fragmentem antykliny/ brachyantykliny Chełma, której oś zanurza się ku południowi (Pożaryski, 1971; Czubla, 1988). Szczyt i południowe stoki są zbudowane z piaskowców albu, a stoki północne z wapieni kimerydu (Kutek, 1968).

Na północ od Przedborza uwagę zwracają inne elementy podłoża. Są to: Góra Majowa, położona na przedłużeniu ku NW Pasma Przedborsko-Małogoskiego (już za przełomem Pilicy) oraz Góra Bąkowa i wychodnie albu w rejonie Kalinek. Najwyraźniejsze w morfologii są Góra Majowa oraz Góra Bąkowa. W tej pierwszej utwory albu i kimerydu są ułożone monoklinalnie, w drugiej - te same utwory zalegają pod niewielkim kątem w osi synkliny (Kutek, 1968).

Wyraźne zróżnicowanie w morfologii powierzchni terenu wpływało niewątpliwie na transgresję lądolodów skandynawskich na ten obszar, zwłaszcza w przypadku starszych zlodowaceń, kiedy deniwelacje ówczesnej powierzchni terenu były większe niż obecnie.

Osady utworzone podczas tych zlodowaceń w rejonie Przedborza stały się przedmiotem badań już dosyć wcześnie. Należy tu wspomnieć o pracy Sawickiego (1922), dotyczącej środkowopolskiej moreny czołowej, i Świdzińskiego (1935). Obaj badacze stwierdzali występowanie licznych głazów narzutowych, eratyków, w rejonie Miejskich Pól, Ludwikowic oraz Bud Nosalewickich, a także w pobliżu wzgórz (morenowych i kemowych) o dość dobrze zachowanych pierwotnych kształtach, przypominających rzeźbę młodoglacjalną.

Późniejsze badania, oparte głównie na pracach kartograficznych, dostarczyły nowych danych i przyczyniły się do szczegółowego rozpoznania osadów czwartorzędowych (por. Jurkiewiczowa, 1965, 1968; Lindner, 1971; Żołnierz, 1971; Cabaj, 1981; Kwapisz, 1983; Wagrowski, 1986, 1987; Wachecka-Kotkowska, Górska-Zabielska, 2010; 


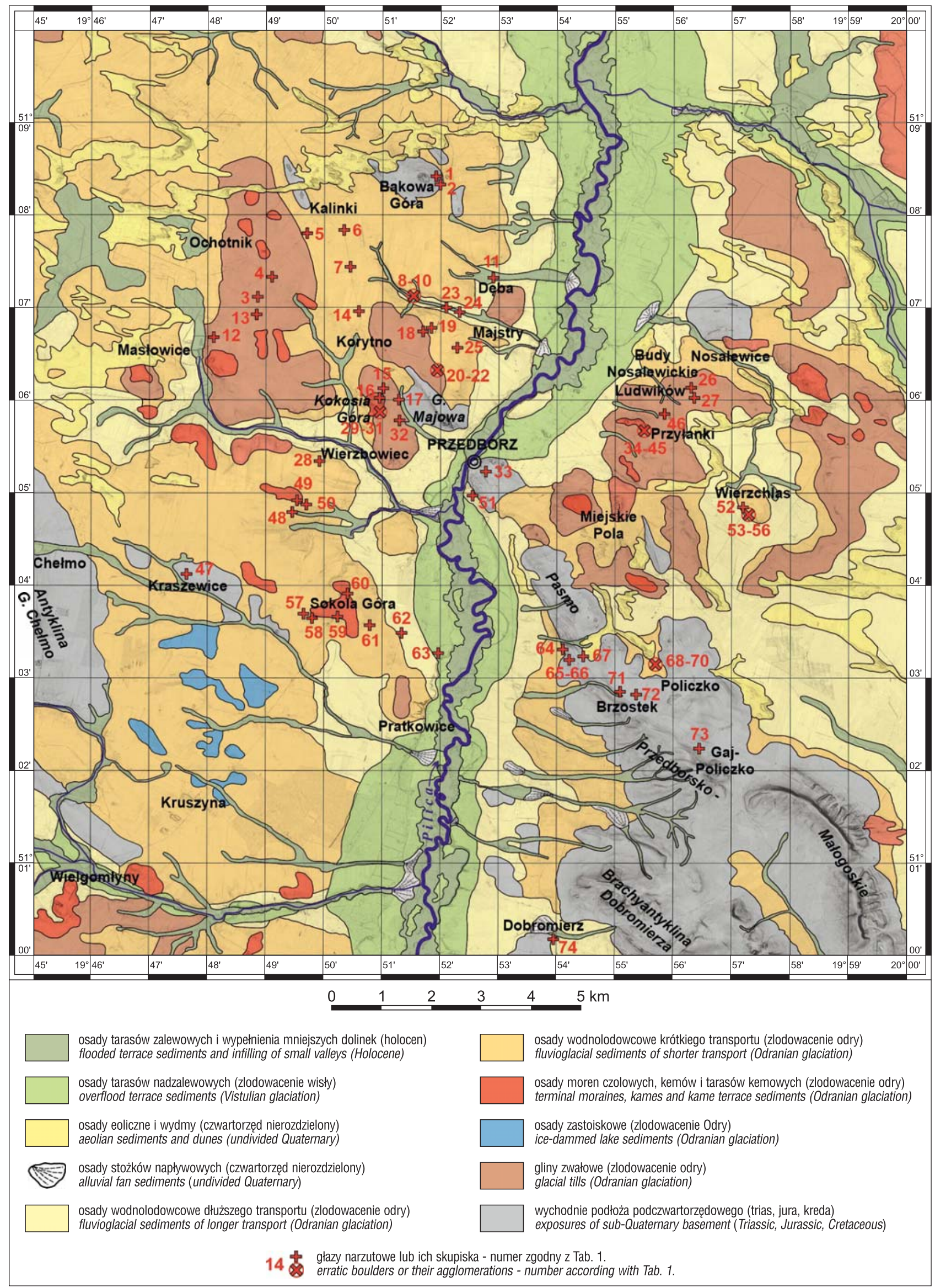

Ryc. 1. Główne rysy powierzchniowej budowy geologicznej obszaru ark. Przedbórz (775) oraz lokalizacja zewidencjonowanych głazów narzutowych lub ich skupisk (por. tab. 1)

Fig. 1. Main features of the surface geological structure of the Przedbórz area (775) and the location of recorded erratic boulders or their clusters (see Table 1) 
Tab. 1. Podstawowe informacje dotyczące głazów narzutowych omawianych w artykule

Table 1. Basic information on erratic boulders discussed in the article

\begin{tabular}{|c|c|c|c|c|c|c|c|c|c|}
\hline $\begin{array}{l}\text { Lp. } \\
\text { No. }\end{array}$ & $\begin{array}{l}\text { Dlug. } \\
\text { Length } \\
{[\mathrm{m}]}\end{array}$ & $\begin{array}{l}\text { Szer. } \\
\text { Width } \\
{[\mathrm{m}]}\end{array}$ & $\begin{array}{l}\text { Wys. } \\
\text { Height } \\
{[\mathrm{m}]}\end{array}$ & $\begin{array}{l}\text { Obw. } \\
\text { Diameter } \\
{[\mathrm{m}]}\end{array}$ & $\begin{array}{c}\text { Obj. } \\
\text { Volume } \\
{\left[\mathrm{m}^{3}\right]}\end{array}$ & $\begin{array}{l}\text { Waga } \\
\text { Weight } \\
{[\mathrm{t}]}\end{array}$ & $\begin{array}{l}\text { Typ petrograficzny } \\
\text { i rodzaj narzutniaka } \\
\text { Petrographic type } \\
\text { and kind of erratic }\end{array}$ & $\begin{array}{l}\text { Szczególne cechy morfologiczne, } \\
\text { inne informacje (np. miejscowość) } \\
\text { Specific morphological features, } \\
\text { other information (e.g. site) }\end{array}$ & $\begin{array}{l}\text { Nr obszaru } \\
\text { alimentacyjnego } \\
\text { na ryc. } 4 \\
\text { Source area } \\
\text { No. in Fig. } 4\end{array}$ \\
\hline 1 & & & & & & & $\begin{array}{l}\text { gnejs oczkowy } \\
\text { augen gneiss }\end{array}$ & \multirow{2}{*}{$\begin{array}{l}\text { Bakkowa Góra } \\
\text { Bąowa Góra }\end{array}$} & \\
\hline 2 & & & & & & & $\begin{array}{l}\text { granit Småland } \\
\text { Småland granite }\end{array}$ & & 2 \\
\hline 3 & 1,65 & 1,00 & 0,80 & 4,60 & 0,69 & 1,90 & $\begin{array}{l}\text { rapakivi alandzkie } \\
\text { Áland rapakivi }\end{array}$ & $\begin{array}{l}\text { okolice Masłowic } \\
\text { near Mastowice }\end{array}$ & 1 \\
\hline 4 & 1,70 & 1,05 & 0,90 & 4,75 & 0,84 & 2,31 & $\begin{array}{l}\text { granit Småland } \\
\text { Småland granite }\end{array}$ & $\begin{array}{l}\text { wygład lodowcowy, zarys grani, } \\
\text { ślady korazji, szlif eoliczny, } \\
\text { Ochotnik } \\
\text { glacial polish, spur outline, } \\
\text { corrasion traces, aeolian cut, } \\
\text { Ochotnik }\end{array}$ & 2 \\
\hline 5 & 1,30 & 1,1 & 0,50 & 4,10 & 0,37 & 1,03 & $\begin{array}{l}\text { granitognejs } \\
\text { granite-gneiss }\end{array}$ & $\begin{array}{l}\text { Ochotnik-Kalinki } \\
\text { Ochotnik-Kalinki }\end{array}$ & \\
\hline 6 & 1,15 & 0,90 & 0,65 & 3,70 & 0,35 & 0,97 & $\begin{array}{l}\text { rapakivi alandzkie } \\
\text { Áland rapakivi }\end{array}$ & $\begin{array}{l}\text { Kalinki } \\
\text { Kalinki }\end{array}$ & 1 \\
\hline 7 & 1,70 & 1,20 & 1,10 & 3,65 & 1,17 & 3,23 & $\begin{array}{l}\text { granit alandzki } \\
\text { Aland granite }\end{array}$ & $\begin{array}{l}\text { liczne ślady korazji, Kalinki } \\
\text { numerous traces of corrasion, } \\
\text { Kalinki }\end{array}$ & 1 \\
\hline 8 & 0,95 & 0,90 & 0,70 & 3,10 & 0,31 & 0,86 & $\begin{array}{l}\text { granit alandzki } \\
\text { Alland granite }\end{array}$ & $\begin{array}{l}\text { omszały, okolice Majstrów } \\
\text { mossy, near Majstry }\end{array}$ & 1 \\
\hline 9 & & & & & & & $\begin{array}{l}\text { piaskowce } \\
\text { Kalmarsund, } \\
\text { granity alandzkie } \\
\text { Kalmarsund } \\
\text { sandstones, } \\
\text { Aland granite } \\
\end{array}$ & $\begin{array}{l}\text { pryzma głazów narzutowych, } \\
\text { okolice Majstrów } \\
\text { heap of erratic boulders, near } \\
\text { Majstry }\end{array}$ & $\begin{array}{l}3 \\
1\end{array}$ \\
\hline 10 & 1,55 & 0,85 & 0,35 & 4,05 & 0,24 & 0,66 & $\begin{array}{l}\text { granit Småland } \\
\text { Småland granite }\end{array}$ & $\begin{array}{l}\text { wygład lodowcowy, okolice } \\
\text { Majstrów } \\
\text { glacial polish, near Majstry }\end{array}$ & 2 \\
\hline 11 & 1,80 & 1,30 & 0,75 & 5,20 & 0,92 & 2,52 & $\begin{array}{l}\text { rapakivi alandzkie } \\
\text { Aland rapakivi }\end{array}$ & $\begin{array}{l}\text { widoczne owoidy typowe dla } \\
\text { alandzkich rapakivi, Dęba } \\
\text { visible ovoides typical of } \AA \text { land } \\
\text { rapakivi, Dęba }\end{array}$ & 1 \\
\hline 12 & 1,10 & 0,95 & 0,30 & 3,70 & 0,16 & 0,45 & $\begin{array}{l}\text { granit } \\
\text { granite }\end{array}$ & $\begin{array}{l}\text { wygład lodowcowy, lekko } \\
\text { zeolizowany, Masłowice } \\
\text { glacial polish, slightly aeolised, } \\
\text { Mastowice }\end{array}$ & \\
\hline 13 & 1,40 & 1,15 & 0,40 & 4,00 & 0,34 & 0,93 & $\begin{array}{l}\text { granit } \\
\text { grubokrystaliczny, } \\
\text { piaskowiec } \\
\text { Kalmarsund } \\
\text { coarse-grained } \\
\text { granite, Kalmarsund } \\
\text { sandstones } \\
\end{array}$ & $\begin{array}{l}\text { pomiary wymiarów dla granitu, } \\
\text { okolice Masłowic } \\
\text { dimensions measurements for } \\
\text { granite, around Mastowice }\end{array}$ & 3 \\
\hline 14 & 2,15 & 1,00 & 0,95 & 5,35 & 1,07 & 2,94 & $\begin{array}{l}\text { granit } \\
\text { drobnokrystaliczny } \\
\text { fine-grained granite }\end{array}$ & $\begin{array}{l}\text { Korytno } \\
\text { Korytno }\end{array}$ & \\
\hline 15 & & & & & & & & $\begin{array}{l}\text { pryzma głazów narzutowych, } \\
\text { Kokosia Góra } \\
\text { heap of erratic boulders, } \\
\text { Kokosia Góra }\end{array}$ & 1 \\
\hline 16 & 1,30 & 1,00 & 0,60 & 4,00 & 0,41 & 1,12 & $\begin{array}{l}\text { rapakivi alandzkie } \\
\text { Åland rapakivi }\end{array}$ & $\begin{array}{l}\text { rzeźba korazyjna pomierzonego } \\
\text { głazu; pryzma głazów narzuto- } \\
\text { wych, Kokosia Góra } \\
\text { corrasive relief of the measured } \\
\text { boulder, heap of the erratic } \\
\text { boulders, Kokosia Góra }\end{array}$ & $\begin{array}{l}2 \\
3\end{array}$ \\
\hline 17 & 1,60 & 0,90 & 0,45 & 4,35 & 0,34 & 0,93 & $\begin{array}{l}\text { granit Småland, } \\
\text { dwa piaskowce } \\
\text { Kalmarsund } \\
\text { Småland granite, } \\
\text { two Kalmarsund } \\
\text { sandstones }\end{array}$ & $\begin{array}{l}\text { eksfoliacja na granicie Småland; } \\
\text { pryzma głazów narzutowych, } \\
\text { region Kokosiej Góry } \\
\text { exfoliation of the Småland } \\
\text { granite, heap of erratic boulders, } \\
\text { Kokosia Góra area }\end{array}$ & \\
\hline 18 & & & & & & & & $\begin{array}{l}\text { największa pryzma głazów } \\
\text { narzutowych, rozciagłość ok. } \\
40 \mathrm{~m} \text {, okolice Korytna } \\
\text { the largest heap of erratic } \\
\text { boulders within the study area, } \\
40 \text { m long, near Korytno }\end{array}$ & \\
\hline
\end{tabular}


Tab. 1. Podstawowe informacje dotyczące głazów narzutowych omawianych w artykule (cd.)

Table 1. Basic information on erratic boulders discussed in the article (cont.)

\begin{tabular}{|c|c|c|c|c|c|c|c|c|c|}
\hline $\begin{array}{l}\text { Lp. } \\
\text { No. }\end{array}$ & $\begin{array}{l}\text { Dlug. } \\
\text { Length } \\
{[\mathrm{m}]}\end{array}$ & $\begin{array}{l}\text { Szer. } \\
\text { Width } \\
{[\mathrm{m}]}\end{array}$ & $\begin{array}{l}\text { Wys. } \\
\text { Height } \\
{[\mathrm{m}]}\end{array}$ & $\begin{array}{l}\text { Obw. } \\
\text { Diameter } \\
{[\mathrm{m}]}\end{array}$ & $\begin{array}{c}\text { Obj. } \\
\text { Volume } \\
{\left[\mathrm{m}^{3}\right]}\end{array}$ & $\begin{array}{c}\text { Waga } \\
\text { Weight } \\
{[\mathrm{t}]}\end{array}$ & $\begin{array}{l}\text { Typ petrograficzny } \\
\text { i rodzaj narzutniaka } \\
\text { Petrographic type } \\
\text { and kind of erratic }\end{array}$ & $\begin{array}{c}\text { Szczególne cechy morfologiczne, } \\
\text { inne informacje (np. miejscowość) } \\
\text { Specific morphological features, } \\
\text { other information (e.g. site) }\end{array}$ & $\begin{array}{l}\text { Nr obszaru } \\
\text { alimentacyjnego } \\
\text { na ryc. } 4 \\
\text { Source area } \\
\text { No. } \text { in Fig. } 4 \\
\end{array}$ \\
\hline 19 & & & & & & & & $\begin{array}{l}\text { niewielkie skupisko głazów } \\
\text { narzutowych, okolice Korytna } \\
\text { small cluster of erratic boulders, } \\
\text { near Korytno }\end{array}$ & \\
\hline 20 & & & & & & & $\begin{array}{l}\text { trzy okazy piaskowca } \\
\text { Kalmarsund } \\
\text { three Kalmarsund } \\
\text { sandstones }\end{array}$ & $\begin{array}{l}\text { niektóre głazy nosza cechy } \\
\text { eolizacji; pryzma głazów narzuto- } \\
\text { wych, region Majowej Góry } \\
\text { some of the boulders [in a heap] } \\
\text { owe features of aeolisation, } \\
\text { Majowa Góra area }\end{array}$ & 3 \\
\hline 21 & & & & & & & & \multirow{2}{*}{$\begin{array}{l}\text { pryzma głazów narzutowych, } \\
\text { region Majowej Góry } \\
\text { heap of erratic boulders, Majowa } \\
\text { Góra area }\end{array}$} & \\
\hline 22 & & & & & & & & & \\
\hline 23 & 1,10 & 0,70 & 0,55 & 2,95 & 0,22 & 0,61 & $\begin{array}{l}\text { granit } \\
\text { granite }\end{array}$ & $\begin{array}{l}\text { eksfoliacja, bardzo dobrze } \\
\text { obtoczony, okolice Majstrów } \\
\text { exfoliation, very well rounded, } \\
\text { near Majstry }\end{array}$ & \\
\hline 24 & & & & & & & $\begin{array}{l}\text { piaskowce } \\
\text { Kalmarsund, granity } \\
\text { Kalmarsund } \\
\text { sandstones, granites }\end{array}$ & $\begin{array}{l}\text { pryzma głazów narzutowych, } \\
\text { okolice Majstrów } \\
\text { heap of erratic boulders, near } \\
\text { Majstry }\end{array}$ & 3 \\
\hline 25 & 1,80 & 1,10 & & & & & $\begin{array}{l}\text { granit Småland, } \\
\text { położenie in situ! } \\
\text { pomiary czéści } \\
\text { widocznej; strop } \\
\text { na rzędnej terenu } \\
\text { Småland granite in } \\
\text { situ! measurements of } \\
\text { the visible part; top of } \\
\text { the boulder at the } \\
\text { ground elevation }\end{array}$ & $\begin{array}{l}\text { na prywatnej posesji w okolicach } \\
\text { Korytna } \\
\text { within a private estate near } \\
\text { Korytno }\end{array}$ & 2 \\
\hline 26 & 0,90 & 0,70 & 0,65 & 3,00 & 0,21 & 0,59 & $\begin{array}{l}\text { rapakivi alandzkie } \\
\text { Åland rapakivi }\end{array}$ & $\begin{array}{l}\text { Ludwików } \\
\text { Ludwików }\end{array}$ & 1 \\
\hline 27 & 0,80 & 0,60 & 0,30 & 2,45 & 0,08 & 0,21 & $\begin{array}{l}2 \times \text { piaskowiec } \\
\text { Kalmarsund, } \\
\text { rapakivi alandzkie } \\
\text { two Kalmarsund } \\
\text { sandstones, } \\
\text { Alland rapakivis }\end{array}$ & $\begin{array}{l}\text { pryzma głazów narzutowych; na } \\
\text { największym okazie rapakivi } \\
\text { wygład lodowcowy, } \\
\text { Ludwików } \\
\text { heap of erratic boulders; glacial } \\
\text { polish on the largest Åland } \\
\text { rapakivi, Ludwików }\end{array}$ & 3 \\
\hline 28 & 2,20 & 1,60 & 0,60 & 6,00 & 1,10 & 3,04 & $\begin{array}{l}\text { granitognejs } \\
\text { granite-gneiss }\end{array}$ & $\begin{array}{l}\text { Wierzbowiec } \\
\text { Wierzbowiec }\end{array}$ & \\
\hline 29 & & & & & & & $\begin{array}{l}5 \mathrm{x} \text { rapakivi } \\
\text { alandzkie, } \\
5 \mathrm{x} \text { piaskowiec } \\
\text { Kalmarsund } \\
\text { five Åland rapakivis, } \\
\text { five Kalmarsund } \\
\text { sandstones }\end{array}$ & $\begin{array}{l}\text { pryzma głazów narzutowych, } \\
\text { Kokosia Góra } \\
\text { heap of erratic boulders, Kokosia } \\
\text { Góra }\end{array}$ & $\begin{array}{l}1 \\
3\end{array}$ \\
\hline \multirow[b]{2}{*}{30} & 1,90 & 1,30 & 1,00 & 6,50 & 1,29 & 3,55 & $\begin{array}{l}\text { granit Blekinge } \\
\text { Blekinge granite }\end{array}$ & $\begin{array}{l}\text { Kokosia Góra } \\
\text { Kokosia Góra }\end{array}$ & 4 \\
\hline & 1,9 & 1,7 & 0,65 & 6,00 & 1,10 & 3,02 & $\begin{array}{l}\text { granit Småland } \\
\text { Småland granite }\end{array}$ & $\begin{array}{l}\text { eksfoliacja powierzchni } \\
\text { głazu,Kokosia Góra } \\
\text { surface exfoliation, Kokosia Góra }\end{array}$ & 2 \\
\hline \multirow[t]{2}{*}{31} & 1,25 & 1,00 & 0,90 & 4,10 & 0,59 & 1,62 & $\begin{array}{l}\text { granit Småland } \\
\text { Småland granite }\end{array}$ & $\begin{array}{l}\text { eksfoliacja grubowarstwowa } \\
1-3 \mathrm{~cm} \text {, rzeźba korazyjna, } \\
\text { Kokosia Góra } \\
\text { thick-layered }(1-3 \mathrm{~cm}) \\
\text { exfoliation, corrasive relief, } \\
\text { Kokosia Góra }\end{array}$ & 2 \\
\hline & 1,50 & 1,05 & 0,75 & 4,10 & 0,62 & 1,70 & $\begin{array}{l}\text { rapakivi alandzkie } \\
\text { Aland rapakivi }\end{array}$ & $\begin{array}{l}\text { ślady rzeźby korazyjnej, } \\
\text { Kokosia Góra } \\
\text { traces of corrasion activity, } \\
\text { Kokosia Góra }\end{array}$ & 1 \\
\hline 32 & & & & & & & & $\begin{array}{l}\text { pryzma głazów narzutowych, } \\
\text { Kokosia Góra } \\
\text { heap of erratic boulders, } \\
\text { Kokosia Góra }\end{array}$ & \\
\hline
\end{tabular}


Tab. 1. Podstawowe informacje dotyczące głazów narzutowych omawianych w artykule (cd.)

Table 1. Basic information on erratic boulders discussed in the article (cont.)

\begin{tabular}{|c|c|c|c|c|c|c|c|c|c|}
\hline $\begin{array}{l}\text { Lp. } \\
\text { No. }\end{array}$ & $\begin{array}{l}\text { Dlug. } \\
\text { Length } \\
{[\mathrm{m}]}\end{array}$ & $\begin{array}{l}\text { Szer. } \\
\text { Width } \\
{[\mathrm{m}]}\end{array}$ & $\begin{array}{l}\text { Wys. } \\
\text { Height } \\
{[\mathrm{m}]}\end{array}$ & $\begin{array}{l}\text { Obw. } \\
\text { Diameter } \\
{[\mathrm{m}]}\end{array}$ & $\begin{array}{c}\text { Obj. } \\
\text { Volume } \\
{\left[\mathrm{m}^{3}\right]}\end{array}$ & $\begin{array}{c}\text { Waga } \\
\text { Weight } \\
{[\mathrm{t}]}\end{array}$ & $\begin{array}{l}\text { Typ petrograficzny } \\
\text { i rodzaj narzutniaka } \\
\text { Petrographic type } \\
\text { and kind of erratic }\end{array}$ & $\begin{array}{l}\text { Szczególne cechy morfologiczne, } \\
\text { inne informacje (np. miejscowość) } \\
\text { Specific morphological features, } \\
\text { other information (e.g. site) }\end{array}$ & $\begin{array}{l}\text { Nr obszaru } \\
\text { alimentacyjnego } \\
\text { na ryc. } 4 \\
\text { Source area } \\
\text { No. in Fig. } 4\end{array}$ \\
\hline 33 & 0,90 & 0,50 & 1,15 & 2,65 & 0,27 & 0,74 & $\begin{array}{l}\text { rapakivi alandzkie } \\
\text { Åland rapakivi }\end{array}$ & $\begin{array}{l}\text { głaz zeolizowany, mikrorzeźba } \\
\text { eoliczna, Przedbórz } \\
\text { boulder with traces of aeolian } \\
\text { activity, eolian microrelief, } \\
\text { Przedbórz }\end{array}$ & 1 \\
\hline 34 & 1,20 & 0,98 & 0,73 & 3,60 & 0,45 & 1,23 & $\begin{array}{l}\text { granit Småland } \\
\text { Småland granite }\end{array}$ & $\begin{array}{l}\text { peknietty, ślady eksfoliacji, } \\
\text { wygład lodowcowy, Przyłanki } \\
\text { cracked, traces of aeolian activity, } \\
\text { glacial polish, Przyłanki }\end{array}$ & 2 \\
\hline 35 & 1,40 & 1,40 & 0,87 & 4,45 & 0,89 & 2,45 & $\begin{array}{l}\text { granit Småland } \\
\text { Småland granite }\end{array}$ & \multirow{3}{*}{$\begin{array}{l}\text { Przyłanki } \\
\text { Przyłanki }\end{array}$} & 2 \\
\hline 36 & 1,10 & 1,10 & 0,50 & 3,50 & 0,32 & 0,87 & $\begin{array}{l}\text { gnejs } \\
\text { gneiss }\end{array}$ & & 2 \\
\hline 37 & 0,46 & 0,36 & 0,30 & 1,65 & 0,03 & 0,07 & $\begin{array}{l}\text { sjenit? } \\
\text { syenite? }\end{array}$ & & \\
\hline 38 & 0,50 & 0,35 & 0,10 & 1,60 & 0,01 & 0,03 & $\begin{array}{l}\text { piaskowiec } \\
\text { Kalmarsund } \\
\text { Kalmarsund } \\
\text { sandstones }\end{array}$ & $\begin{array}{l}\text { plamy postsedymentacyjne, } \\
\text { Przyłanki } \\
\text { postsedimentary stains, Przytanki }\end{array}$ & 3 \\
\hline 39 & 0,85 & 0,55 & 0,15 & 1,00 & & & $\begin{array}{l}\text { granit kwarcowy, } \\
\text { granit Småland (?) } \\
\text { niebieskawe okragłe } \\
\text { kwarce, duże skalenie } \\
\text { quartz granite, } \\
\text { Småland granite (?) } \\
\text { bluish round quartzes, } \\
\text { large feldspars }\end{array}$ & $\begin{array}{l}\text { wymiary widocznej części głazu, } \\
\text { Przyłanki } \\
\text { measurements of the visible part } \\
\text { of the boulder, Przyłanki }\end{array}$ & \\
\hline 40 & 0,45 & 0,25 & 0,40 & 1,20 & 0,02 & 0,06 & $\begin{array}{l}\text { granit } \\
\text { drobnokrystaliczny } \\
\text { fine-grained granite }\end{array}$ & $\begin{array}{l}\text { na wygładzie rysy polodowcowe, } \\
\text { Przyłanki } \\
\text { striae on a glacial polish, } \\
\text { Przylanki }\end{array}$ & \\
\hline 41 & 0,45 & 0,40 & 0,20 & 1,60 & 0,02 & 0,05 & $\begin{array}{l}\text { piaskowiec } \\
\text { Kalmarsund } \\
\text { Kalmarsund } \\
\text { sandstones } \\
\end{array}$ & $\begin{array}{l}\text { Przyłanki } \\
\text { Przyłanki }\end{array}$ & 3 \\
\hline 42 & 0,90 & 0,80 & 0,30 & 2,75 & 0,11 & 0,31 & $\begin{array}{l}\text { granit Småland } \\
\text { Småland granite }\end{array}$ & $\begin{array}{l}\text { dobrze obtoczony, Przyłanki } \\
\text { well rounded, Przyłanki }\end{array}$ & 2 \\
\hline 43 & 0,75 & 0,45 & 0,35 & 2,30 & 0,06 & 0,17 & $\begin{array}{l}\text { granit alandzki } \\
\text { Alland rapakivi }\end{array}$ & $\begin{array}{l}\text { doskonale widoczna struktura } \\
\text { rapakivi, mikrorzeźba korazyjna, } \\
\text { Przyłanki } \\
\text { perfectly visible rapakivi } \\
\text { structure, corrasive microrelief, } \\
\text { Przyłanki }\end{array}$ & 1 \\
\hline 44 & 0,55 & 0,55 & 0,55 & 2,00 & 0,09 & 0,24 & $\begin{array}{l}\text { granit alandzki } \\
\text { Aland rapakivi }\end{array}$ & $\begin{array}{l}\text { Przyłanki } \\
\text { Przylanki }\end{array}$ & 1 \\
\hline 45 & 0,87 & 0,35 & 0,20 & 2,15 & 0,03 & 0,09 & $\begin{array}{l}\text { granit Småland } \\
\text { Småland granite }\end{array}$ & $\begin{array}{l}\text { naturalnie peknietty, Przyłanki } \\
\text { naturally cracked, Przyłanki }\end{array}$ & 2 \\
\hline 46 & 1,65 & 1,25 & 0,60 & 4,80 & 0,65 & 1,78 & $\begin{array}{l}\text { granit Blekinge } \\
\text { Blekinge granite }\end{array}$ & $\begin{array}{l}\text { Ludwików } \\
\text { Ludwików }\end{array}$ & 4 \\
\hline 47 & 1,35 & 1,20 & 1,10 & 3,75 & 0,93 & 2,56 & $\begin{array}{l}\text { granit czerwony } \\
\mathrm{z} \text { żyłą pegmatytową } \\
\text { red granite with } \\
\text { pegmatite vein } \\
\end{array}$ & $\begin{array}{l}\text { głaz pęknięty na powierzchni } \\
\text { żyły, zwietrzały, Kraszewice } \\
\text { boulder cracked on the vein } \\
\text { surface, weathered, Kraszewice }\end{array}$ & \\
\hline 48 & 1,95 & 1,75 & 0,45 & 5,90 & 0,80 & 2,21 & $\begin{array}{l}\text { granit } \\
\text { grubokrystaliczny } \\
\text { coarse-grained } \\
\text { granite }\end{array}$ & $\begin{array}{l}\text { Wierzbowiec } \\
\text { Wierzbowiec }\end{array}$ & \\
\hline 49 & 1,15 & 1,10 & 0,90 & 3,50 & 0,60 & 1,64 & $\begin{array}{l}\text { granit } \\
\text { grubokrystaliczny } \\
\text { Småland } \\
\text { Småland } \\
\text { coarse-grained } \\
\text { granite }\end{array}$ & $\begin{array}{l}\text { rzeźba korazyjna, wygład } \\
\text { lodowcowy, Wierzbowiec } \\
\text { corrasive relief, glacial polish, } \\
\text { Wierzbowiec }\end{array}$ & 2 \\
\hline 50 & 1,95 & 1,10 & 0,80 & 5,40 & 0,90 & 2,47 & $\begin{array}{l}\text { jasny granit } \\
\text { bright granite }\end{array}$ & $\begin{array}{l}\text { obtoczony ze wszystkich stron, } \\
\text { Wierzbowiec } \\
\text { abraded on all sides, Wierzbowiec }\end{array}$ & \\
\hline 51 & 0,95 & 0,80 & 0,75 & 3,00 & 0,30 & 0,82 & $\begin{array}{l}\text { granit jasnoszary } \\
\text { light grey granite }\end{array}$ & $\begin{array}{l}\text { głaz bardzo zwietrzały, Przedbórz } \\
\text { highly weatherd boulder, } \\
\text { Przedbórz }\end{array}$ & \\
\hline
\end{tabular}


Tab. 1. Podstawowe informacje dotyczące głazów narzutowych omawianych w artykule (cd.)

Table 1. Basic information on erratic boulders discussed in the article (cont.)

\begin{tabular}{|c|c|c|c|c|c|c|c|c|c|}
\hline $\begin{array}{l}\text { Lp. } \\
\text { No. }\end{array}$ & $\begin{array}{l}\text { Dlug. } \\
\text { Length } \\
{[\mathrm{m}]}\end{array}$ & $\begin{array}{l}\text { Szer. } \\
\text { Width } \\
{[\mathrm{m}]}\end{array}$ & $\begin{array}{l}\text { Wys. } \\
\text { Height } \\
{[\mathrm{m}]}\end{array}$ & $\begin{array}{l}\text { Obw. } \\
\text { Diameter } \\
{[\mathrm{m}]}\end{array}$ & $\begin{array}{c}\text { Obj. } \\
\text { Volume } \\
{\left[\mathrm{m}^{3}\right]}\end{array}$ & $\begin{array}{c}\text { Waga } \\
\text { Weight } \\
{[\mathrm{t}]}\end{array}$ & $\begin{array}{l}\text { Typ petrograficzny } \\
\text { i rodzaj narzutniaka } \\
\text { Petrographic type } \\
\text { and kind of erratic }\end{array}$ & $\begin{array}{l}\text { Szczególne cechy morfologiczne, } \\
\text { inne informacje (np. miejscowość) } \\
\text { Specific morphological features, } \\
\text { other information (e.g. site) }\end{array}$ & $\begin{array}{l}\text { Nr obszaru } \\
\text { alimentacyjnego } \\
\text { na ryc. } 4 \\
\text { Source area } \\
\text { No. } \text { in Fig. } 4\end{array}$ \\
\hline 52 & 0,95 & 0,75 & 0,48 & 3,20 & 0,18 & 0,49 & $\begin{array}{l}\text { granit } \\
\text { granite }\end{array}$ & \multirow{4}{*}{$\begin{array}{l}\text { Wierzchlas } \\
\text { Wierzchlas }\end{array}$} & \\
\hline 53 & 1,40 & 1,10 & 0,75 & 4,05 & 0,60 & 1,66 & $\begin{array}{l}\text { granit } \\
\text { drobnokrystaliczny } \\
\text { fine-grained granite }\end{array}$ & & \\
\hline 54 & 1,40 & 1,40 & 0,40 & 4,50 & 0,41 & 1,13 & $\begin{array}{l}\text { granit } \\
\text { drobnokrystaliczny } \\
\text { z żyłą pegmatytową } \\
\text { fine-grained granite } \\
\text { with pegmatite vein }\end{array}$ & & \\
\hline 55 & 1,35 & 0,95 & 0,75 & 4,20 & 0,50 & 1,38 & $\begin{array}{l}\text { granit Småland, } \\
\text { zgnejsowiały } \\
\text { Småland granite, } \\
\text { gneissed }\end{array}$ & & 2 \\
\hline 56 & 1,15 & 1,10 & 0,75 & 3,75 & 0,50 & 1,36 & $\begin{array}{l}\text { rapakivi alandzkie } \\
\text { Aland rapakivi }\end{array}$ & $\begin{array}{l}\text { omszaly, pokryty porostami, } \\
\text { Wierzchlas } \\
\text { mossy, covered with lichen, } \\
\text { Wierzchlas }\end{array}$ & 1 \\
\hline 57 & & & & & & & $\begin{array}{l}\text { gnejs } \\
\text { gneiss }\end{array}$ & \multirow[b]{2}{*}{$\begin{array}{l}\text { Sokola Góra } \\
\text { Sokola Góra }\end{array}$} & \\
\hline 58 & 1,70 & 0,75 & 0,70 & 4,05 & 0,47 & 1,28 & $\begin{array}{l}\text { granit z żyłami } \\
\text { pegmatytowymi } \\
\text { granite with pegmatite } \\
\text { veins }\end{array}$ & & \\
\hline 59 & 1,20 & 0,85 & 0,55 & 3,40 & 0,29 & 0,81 & $\begin{array}{l}\text { granit alandzki z żyłą } \\
\text { pegmatytowa } \\
\text { Åland granite with } \\
\text { pegmatite vein }\end{array}$ & $\begin{array}{l}\text { głaz w pozycji in situ! pomiar } \\
\text { cześci głazu ponad powierzchnia } \\
\text { terenu, Sokola Góra } \\
\text { boulder in situ! measurements of } \\
\text { the part of the boulder above the } \\
\text { ground, Sokola Góra }\end{array}$ & 1 \\
\hline 60 & 1,40 & 1,30 & 0,70 & 4,75 & 0,67 & 1,83 & $\begin{array}{l}\text { granit } \\
\text { drobnokrystaliczny, } \\
\text { rapakivi alandzkie } \\
\text { fine-grained granite, } \\
\text { Åland rapakivi }\end{array}$ & \multirow{2}{*}{$\begin{array}{l}\text { rzeźba korazyjna, Sokola Góra } \\
\text { corrasive relief, Sokola Góra }\end{array}$} & 1 \\
\hline 61 & 1,38 & 0,95 & 0,55 & 3,75 & 0,38 & 1,04 & $\begin{array}{l}\text { czerwony granit } \\
\text { grubokrystaliczny } \\
\text { z żyła pegmatytowa } \\
\text { red coarse-grained } \\
\text { granite with pegmatite } \\
\text { vein }\end{array}$ & & \\
\hline 62 & 1,85 & 1,60 & 0,55 & 5,30 & 0,85 & 2,34 & $\begin{array}{l}\text { granit kwarcowy } \\
\text { alandzki, } \\
\text { grubokrystaliczny } \\
\text { Aland coarse-grained, } \\
\text { quartz granite }\end{array}$ & $\begin{array}{l}\text { rzeźba korazyjna, wygład } \\
\text { lodowcowy, Pratkowice-Sokola } \\
\text { Góra } \\
\text { corrasive relief, glacial polish, } \\
\text { Pratkowice-Sokola Góra }\end{array}$ & 1 \\
\hline 63 & 2,40 & 1,50 & 1,00 & 6,00 & 1,88 & 5,18 & $\begin{array}{l}\text { granit z żyłą } \\
\text { pegmatytowa, szary } \\
\text { grey granite with } \\
\text { pegmatite vein }\end{array}$ & $\begin{array}{l}\text { rzeźba korazyjna, wygład } \\
\text { lodowcowy, najwieksszy głaz } \\
\text { narzutowy obszaru badan, } \\
\text { Pratkowice } \\
\text { corrasive relief, glacial polish, } \\
\text { the largest erratic boulder within } \\
\text { the study area, Pratkowice }\end{array}$ & \\
\hline 64 & 0,90 & 0,85 & 0,55 & 3,00 & 0,22 & 0,61 & $\begin{array}{l}\text { granit Småland } \\
\text { Småland granite }\end{array}$ & $\begin{array}{l}\text { mikrorzeźba eoliczna, okolice } \\
\text { Brzostka } \\
\text { aeolian microrelief, near Brzostek }\end{array}$ & 2 \\
\hline 65 & 0,90 & 0,65 & 0,50 & 2,70 & 0,15 & 0,42 & $\begin{array}{l}\text { granit Småland, } \\
\text { z żyłami, jasnoszary } \\
\text { light grey Småland } \\
\text { granite with veins }\end{array}$ & $\begin{array}{l}\text { okolice Brzostka } \\
\text { around Brzostek }\end{array}$ & 2 \\
\hline 66 & 1,10 & 0,55 & 0,38 & 3,15 & 0,12 & 0,33 & $\begin{array}{l}\text { granit } \\
\text { czerwono-czarny } \\
\text { red-black granite }\end{array}$ & $\begin{array}{l}\text { głaz zakotwiczony w podłożu, } \\
\text { wymiary cześci widocznej, } \\
\text { okolice Brzostka } \\
\text { the boulder anchored in the } \\
\text { ground, dimensions of the visible } \\
\text { part, near Brzostek }\end{array}$ & \\
\hline 67 & 0,75 & 0,75 & 0,75 & 2,30 & 0,22 & 0,61 & $\begin{array}{l}\text { granitognejs - gnejs } \\
\text { oczkowy } \\
\text { granite-gneiss - } \\
\text { augen gneiss }\end{array}$ & $\begin{array}{l}\text { okolice Brzostka } \\
\text { near Brzostek }\end{array}$ & \\
\hline
\end{tabular}


Tab. 1. Podstawowe informacje dotyczące głazów narzutowych omawianych w artykule (cd.)

Table 1. Basic information on erratic boulders discussed in the article (cont.)

\begin{tabular}{|c|c|c|c|c|c|c|c|c|c|}
\hline $\begin{array}{l}\text { Lp. } \\
\text { No. }\end{array}$ & $\begin{array}{l}\text { Dlug. } \\
\text { Length } \\
{[\mathrm{m}]}\end{array}$ & $\begin{array}{l}\text { Szer. } \\
\text { Width } \\
{[\mathrm{m}]}\end{array}$ & $\begin{array}{l}\text { Wys. } \\
\text { Height } \\
{[\mathrm{m}]}\end{array}$ & $\begin{array}{l}\text { Obw. } \\
\text { Diameter } \\
{[\mathrm{m}]}\end{array}$ & $\begin{array}{c}\text { Obj. } \\
\text { Volume } \\
{\left[\mathrm{m}^{3}\right]}\end{array}$ & $\begin{array}{c}\text { Waga } \\
\text { Weight } \\
\text { [t] }\end{array}$ & $\begin{array}{l}\text { Typ petrograficzny } \\
\text { i rodzaj narzutniaka } \\
\text { Petrographic type } \\
\text { and kind of erratic }\end{array}$ & $\begin{array}{c}\text { Szczególne cechy morfologiczne, } \\
\text { inne informacje (np. miejscowość) } \\
\text { Specific morphological features, } \\
\text { other information (e.g. site) }\end{array}$ & $\begin{array}{l}\text { Nr obszaru } \\
\text { alimentacyjnego } \\
\text { na ryc. } 4 \\
\text { Source area } \\
\text { No. } \text { in Fig. } 4 \\
\end{array}$ \\
\hline 68 & 1,45 & 1,20 & 0,70 & 4,15 & 0,64 & 1,75 & $\begin{array}{l}\text { granit Småland } \\
\text { Småland granite }\end{array}$ & $\begin{array}{l}\text { wygład lodowcowy, zarys grani, } \\
\text { mikrożebra korazyjne, Policzko } \\
\text { glacial polish, spur outline, } \\
\text { corrasive microribs, Policzko }\end{array}$ & \\
\hline 69 & 0,95 & 0,70 & 0,50 & 2,55 & 0,17 & 0,48 & $\begin{array}{l}\text { rapakivi alandzkie } \\
\text { Aland rapakivi }\end{array}$ & $\begin{array}{l}\text { głaz obtoczony, z wygładem } \\
\text { lodowcowym, Policzko } \\
\text { abraded boulder with glacial } \\
\text { polish, Policzko }\end{array}$ & 1 \\
\hline 70 & 0,85 & 0,68 & 0,55 & 2,65 & 1,66 & 4,57 & $\begin{array}{l}\text { rapakivi alandzkie } \\
\text { Aland rapakivi }\end{array}$ & $\begin{array}{l}\text { rysy polodowcowe, zwietrzały, } \\
\text { Policzko } \\
\text { striae, weathered, Policzko }\end{array}$ & 1 \\
\hline 71 & 1,10 & 0,85 & 0,55 & 3,25 & 0,27 & 0,74 & $\begin{array}{l}\text { granit silnie } \\
\text { zgejsowiały } \\
\text { granite strongly } \\
\text { gneissed }\end{array}$ & \multirow{2}{*}{$\begin{array}{l}\text { okolice Brzostka } \\
\text { around Brzostek }\end{array}$} & \\
\hline 72 & 2,05 & 1,50 & 0,60 & 5,30 & 0,96 & 2,65 & $\begin{array}{l}\text { granit Blekinge ze } \\
\text { zbliźniaczonymi } \\
\text { skaleniami } \\
\text { Blekinge granite with } \\
\text { twinning feldspars }\end{array}$ & & 4 \\
\hline 73 & 1,10 & 0,95 & 0,77 & 3,35 & 0,42 & 1,16 & $\begin{array}{l}\text { granit } \\
\text { drobnokrystaliczny } \\
\text { z żyłami } \\
\text { fine-grained granite } \\
\text { with veins }\end{array}$ & $\begin{array}{l}\text { rysy polodowcowe, głaz } \\
\text { obtoczony, Gaj Policzko } \\
\text { striae, abraded boulder, } \\
\text { Gaj Policzko }\end{array}$ & \\
\hline 74 & 1,20 & 0,60 & 0,95 & 3,50 & 0,36 & 0,98 & $\begin{array}{l}\text { granit Småland z żyłą } \\
\text { pegmatytową } \\
\text { Småland granite with } \\
\text { pegmatite veins }\end{array}$ & $\begin{array}{l}\text { głaz lekko zeolizowany, } \\
\text { Dobromierz } \\
\text { slightly aeolised boulder, } \\
\text { Dobromierz }\end{array}$ & 2 \\
\hline
\end{tabular}

Objętość głazów wyliczano na podstawie wzoru: 0,523 $\times$ długość $\times$ szerokość $\times$ wysokość, a wagę - przyjmując, że $1 \mathrm{~m}^{3}=2,75 \mathrm{t}($ Schulz, 1999$)$. The volume of boulders was calculated on the basis of the formula: $0.523 \times$ length $\times$ width $\times$ height, and weight calculated assuming that $1 \mathrm{~m}^{3}=2.75 t$ (Schulz, 1999).

Wachecka-Kotkowska, 2013, 2015a, b; Wachecka-Kotkowska i in., 2013, 2017a, b). Ostatnio przeprowadzono prace aktualizacyjne dla arkusza Przedbórz (775) SMGP $1: 50000$ (Wieczorek i in., 2020a, b).

$\mathrm{Na}$ powierzchni terenu występują tutaj serie glacjalne oraz fluwioglacjalne związane ze zlodowaceniem odry sensu Lindner i Marks (2012), które obecnie odnosi się do MIS 6 (szóstego stadium krzywej izotopowej tlenu $\mathrm{O}^{16}$ i $\mathrm{O}^{18}$ w osadach morskich). Ponadto podczas deglacjacji zaznaczył się tutaj stadiał warty (por. Wachecka-Kotkowska, 2015a), którego przebieg dokumentuje szereg form charakterystycznych dla strefy glacimarginalnej (por. Wieczorek i in., 2020a, b). Składają się na nią głównie wzgórza moren czołowych oraz mniej liczne kemy, a także terasy kemowe. Niektóre wzgórza morenowe bardzo wyraźne zaznaczają się w rzeźbie terenu, dotyczy to zwłaszcza rejonu Sokolej Góry, Wielgomłynów, Masłowic, Przedborza (Kokosia Góra), Miejskich Pól oraz Nosalewic.

W rejonie Wierzchlasu, na wschód od Przedborza, znajduje się stożek glacimarginalny o amfiteatralnym kształcie odzwierciedlającym zasięg dawnej krawędzi lądolodu (sedymentacyjna krawędź lobowa sensu Kasprzak, 2003). W strefie wyraźnego obniżenia w tej formie (dawna brama lodowa) rozpościera się proksymalna część rozległego sandru, wskazującego na odpływ wód roztopowych ku SE.

Starsze utwory plejstoceńskie występują pod przykryciem osadów odrzańskich. Brak jest tutaj osadów, które można by korelować z MIS 8 czy MIS 10 (zlod. krzny i liwca sensu Lindner, Marks, 2012). Są natomiast utwory, które należy korelować ze zlodowaceniem sanu 2 (MIS 12) i sanu 1 (MIS 16) (por. Wieczorek i in., 2020a, b).

Podczas badań terenowych prowadzonych nad głazami narzutowymi z rejonu Przedborza poruszano się głównie w sąsiedztwie form marginalnych zlodowacenia odry (MIS 6).

\section{METODYKA BADAŃ}

W ramach prac terenowych związanych z aktualizacją arkusza Przedbórz (775) Szczegółowej Mapy Geologicznej Polski w skali 1 : 50 000, w latach 2018-2019 zinwentaryzowano większość (w liczbie ok. 1600) głazów narzutowych lub miejsca ich antropogenicznego nagromadzenia (w tzw. pryzmach) występujących na obszarze badań. Do lokalizacji głazów użyto odbiornika GPS firmy Garmin. Otrzymano mapę rozmieszczenia zinwentaryzowanych głazów (ryc. 2).

W lipcu 2020 r. sporządzono szczegółową charakterystykę wybranych 74 okazów (tab. 1). Wybór głazów był częściowo subiektywny - szczególną uwagę zwracano na obecność narzutniaków przewodnich (np. Lüttig, 1958; Czubla i in., 2006; Meyer, Lüttig, 2007; Górska-Zabielska, 2008) oraz na głazy o dużych gabarytach. Narzutniaki przewodnie są istotne, ponieważ są unikalne, bo mają tylko jedną wychodnię na Półwyspie Skandynawskim (ryc. 4), dzięki czemu można dokładnie wskazać ich obszar alimentacyjny. Zebrano wówczas informacje dotyczące wymiarów, typu petrograficznego i rodzaju eratyka oraz cech 


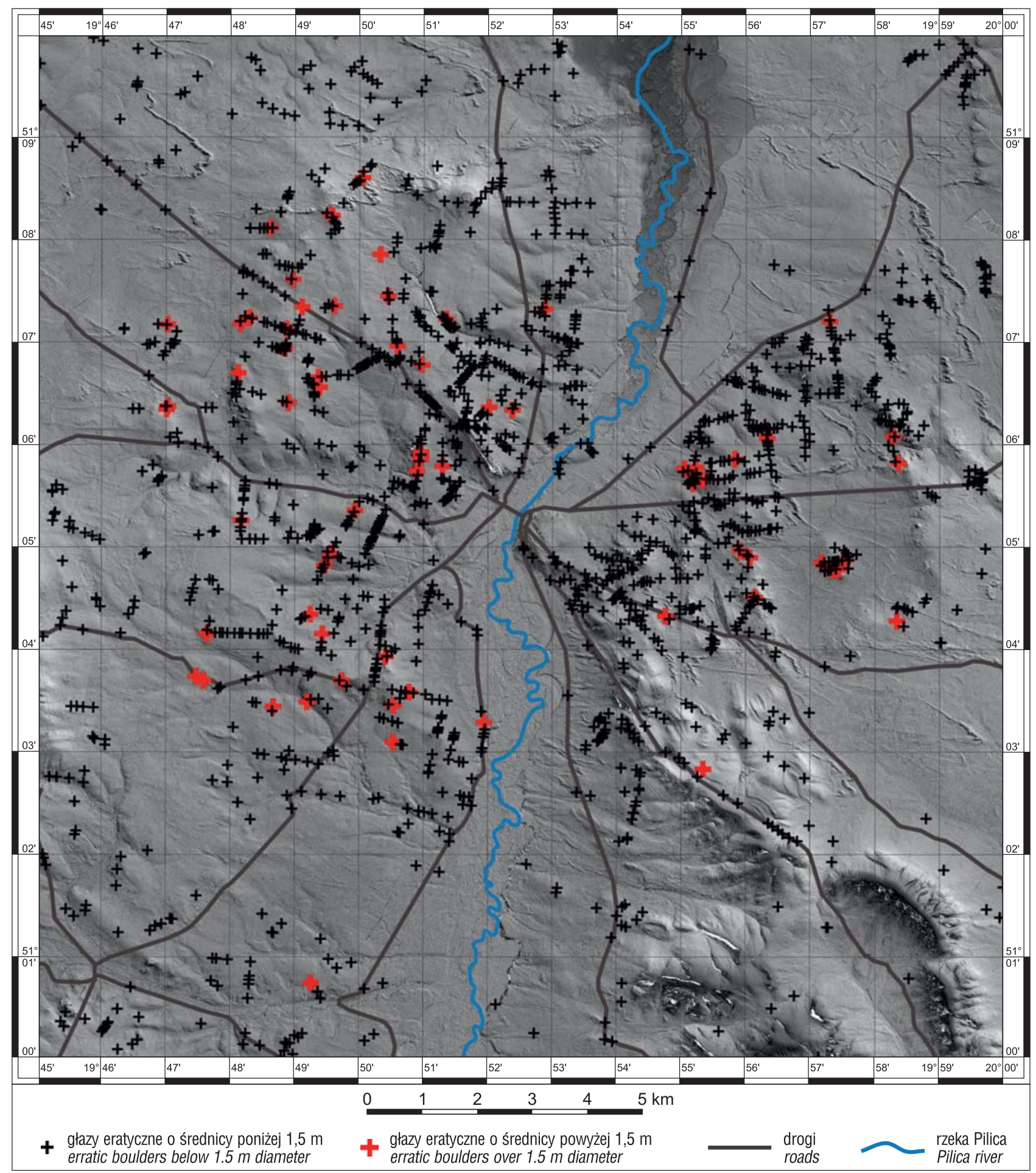

Ryc. 2. Szkic rozmieszczenia głazów narzutowych na obszarze ark. Przedbórz (775)

Fig. 2. Sketch of the distribution of glacial boulders in the area of Przedbórz sheet (775)

szczególnych. Szacunkową objętość głazów wyliczano na podstawie wzoru Schulza (1999): 0,523 × długość $\times$ szerokość $\times$ wysokość, a ciężar - przyjmując, że $1 \mathrm{~m}^{3}=2,75 \mathrm{t}$. Badania narzutniaków przewodnich, wykorzystywane m.in. w celu określenia kierunków głównego transportu glacjalnego, metodycznie wykonuje się we frakcji grubożwirowej (20-60 mm; Meyer, 1983). Wskazują one, że w całej populacji narzutniaków na Niżu Europejskim zaledwie w ok. $10 \%$ to narzutniaki przewodnie, więc należą one do rzadkości. Natomiast głazy o znacznych gabarytach są istotne z punktu widzenia waloryzacji turystycznej i możliwym wykorzystaniem ich potencjału edukacyjnego oraz geoturystycznego w przyszłości.

Zwracano uwage na zapisane na powierzchni głazu narzutowego rozmaite mikroformy w postaci np. połksiężycowatych zadziorów czy wygładów lodowcowych, których powstanie jest charakterystyczne dla środowiska subglacjalnego, gdy głaz transportowany w stopie lądolodu tarł o twardsze niż ów głaz podłoże. Badano również stan naroży, tj. ich obróbkę, będącą dowodem na transport $\mathrm{w}$ wysokoenergetycznych tunelach sub- i inglacjalnych. Udokumentowano także charakterystyczne cechy mikromorfologiczne, jakie zapisały się na powierzchni głazu 


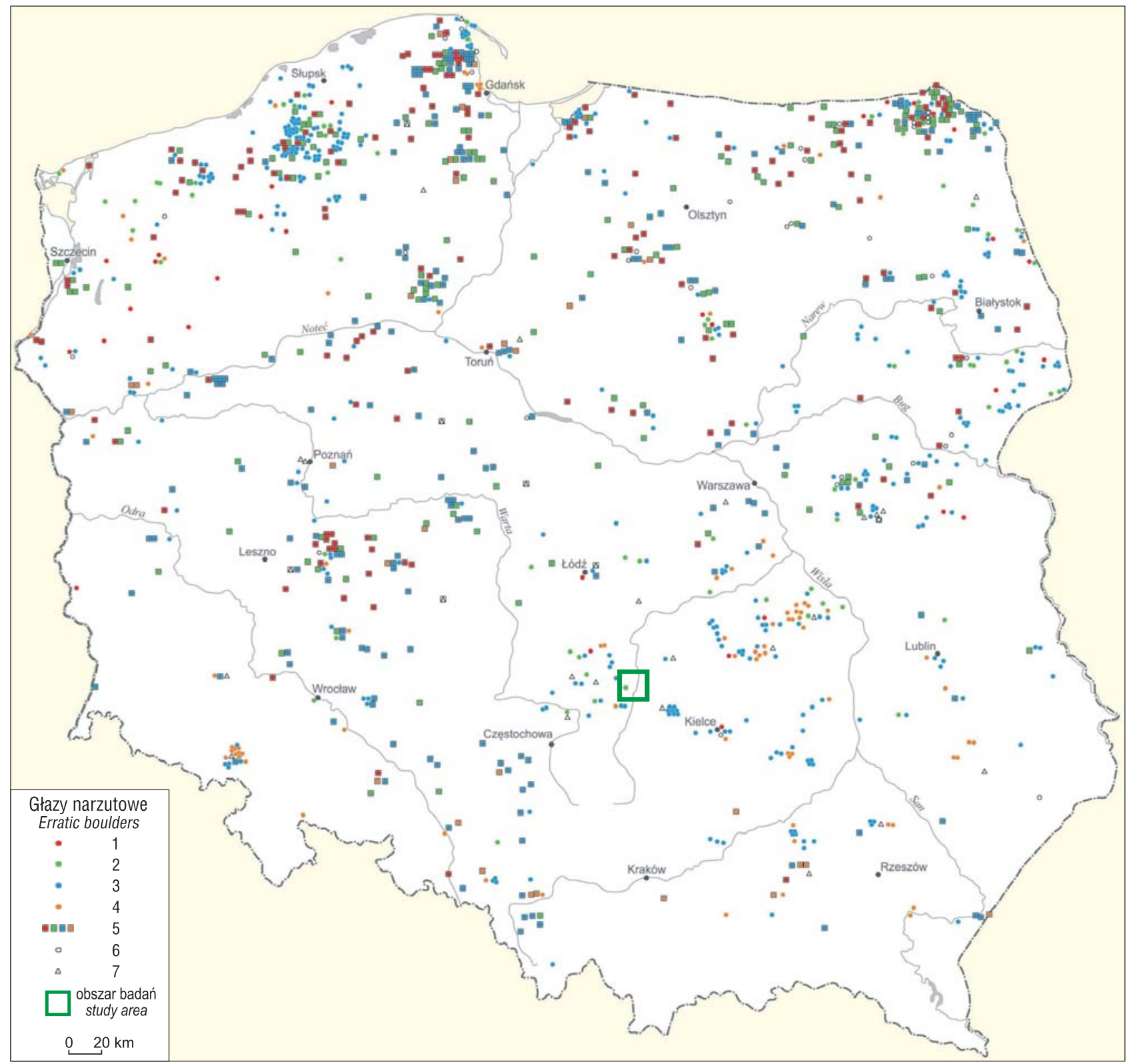

Ryc. 3. Rozmieszczenie głazów narzutowych w Polsce (Czernicka-Chodkowska, 1977, 1980, 1983). Obwód głazów: 1 - powyżej 10 m, 2 - 8-10 m, 3-4-8 m, 4 - poniżej $4 \mathrm{~m}, 5$ - głazowiska prawnie chronione, 6 - głazowiska naturalne, 7 -głazowiska sztuczne

Fig. 3. Distribution of erratic boulders in Poland (Czernicka-Chodkowska, 1977, 1980, 1983). Boulder perimeter: 1 - greater than $10 \mathrm{~m}$, 2-8-10 m, 3-4-8 m, 4-smaller than $4 \mathrm{~m}, 5$ - boulder clusters legally protected, 6 - natural, 7 - artificial

w środowisku peryglacjalnym (np. ślady korazji, eologliptolity, graniaki). Oddziałujące współcześnie na powierzchnię głazu procesy morfogenetyczne (np. eksfoliacja, korazja, kolonizacja florą epilityczną; np. Górska-Zabielska, 2015; Górska-Zabielska i in., 2020) były również przedmiotem analizy terenowej.

Fotografie w 2020 r. wykonała M. Górska-Zabielska, chyba, że podano inaczej.

\section{WYNIKI}

Głazy narzutowe na arkuszu Przedbórz występują powszechnie, ale w lokalizacji nieznacznie zmienionej w stosunku do in situ - są one nagromadzone wzdłuź śródpolnych miedz lub polnych dróg, dokąd zostały przemieszczone przez człowieka z powierzchni najbliższych pól. Ich lokalizacja, w granicach obszaru badań, raczej nie wykazuje wyraźnego uporządkowania w kontekście rzeźby terenu (ryc. 2). Część głazów występuje w grupach kilku-kilkunastu sztuk lub pojedynczo. Pozostałe są nagromadzone i ułożone w postaci tzw. pryzm, w pobliżu miedz lub dróg polnych, tak, aby zmniejszyć ich ilość na uprawianych gruntach.

Wśród 74 wybranych do szczegółowego opisu narzutniaków, aż 49 stanowią eratyki przewodnie - taki wysoki ich udział wynika ze wspominanego wcześniej subiektywizmu przy selekcji głazów. Wśród nich dominują łatwo rozpoznawalne alandzkie granity rapakivi (19 sztuk; pochodzenie oznaczono nr 1 na ryc. 4), granity Småland (18 szt.; nr 2 na ryc. 4) oraz piaskowce Kalmarsund (9 szt.; nr 3 na ryc. 4).

Dobrze zachowany narzutniak z Wysp Alandzkich występuje m.in. w miejscowości Przyłanki (nr 43), z doskonale widoczną strukturą rapakivi (ryc. 5) oraz głaz (nr 33) w Przedborzu, stojący przed budynkiem Straży Pożarnej. Ten ostatni pełni rolę kulturotwórczą, stanowiąc podstawę 
pod okolicznościową tablicą upamiętniającą bohaterskich przedborskich strażaków, którzy zginęli w okresie II wojny światowej. Pozostałe alandzkie granity rapakivi znajdują się w stanowiskach numer: 3, 6, 11, 16, 26, 27, 29, 31, 33, 56, 60, 69 i 70 (tab. 1).

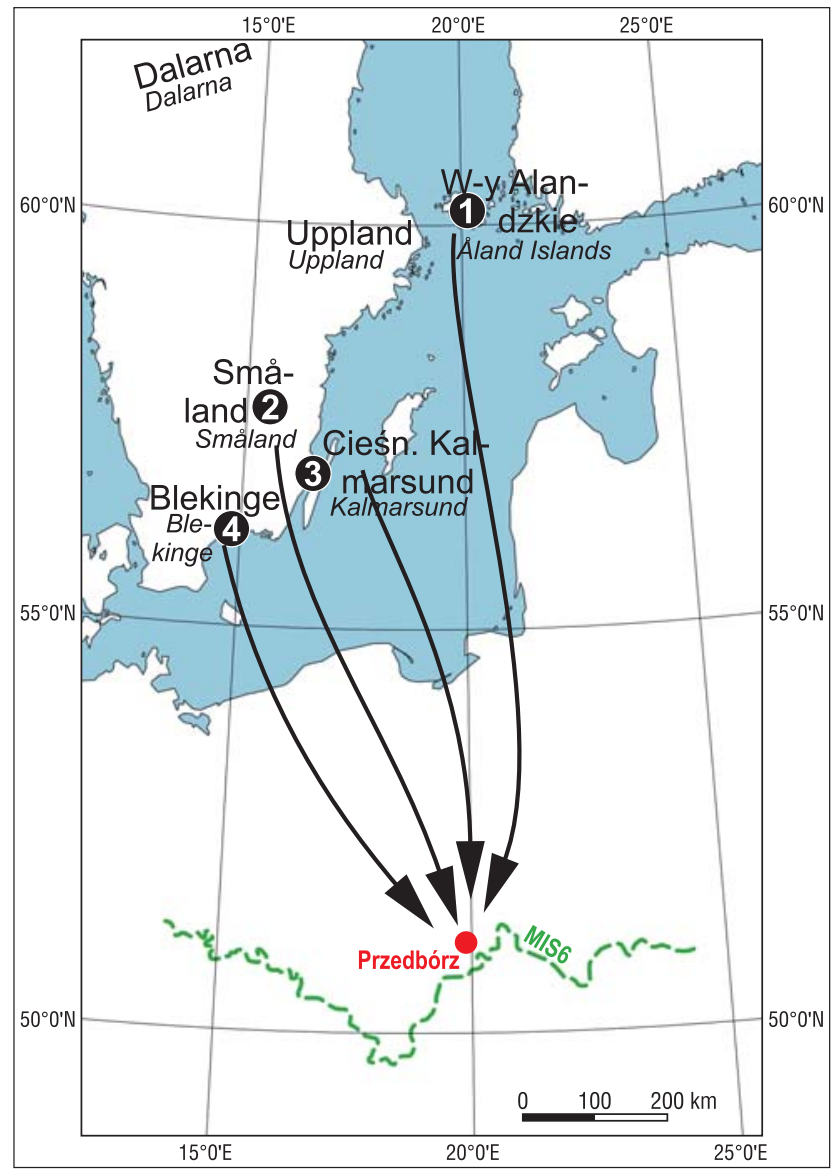

Ryc. 4. Schematyczna mapa obszarów źródłowych głazów narzutowych okolic Przedborza (maksymalny zasięg lądolodu skandynawskiego podczas MIS6 wg Marksa i in., 2016)

Fig. 4. Schematic map of the source areas of erratic boulders near Przedbórz (the maximum extent of the Scandinavian ice sheet during MIS6 acc. to Marks et al., 2016)

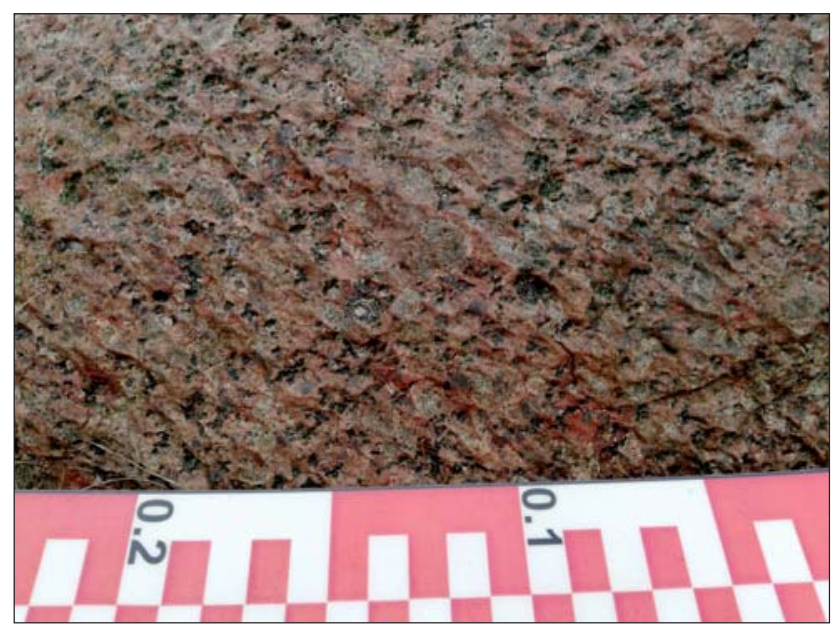

Ryc. 5. Wydłużone, równoległe mikrownęki genezy korazyjnej wykształcone na alandzkim granicie rapakivi w Przyłankach (nr 43 na ryc. 1)

Fig. 5. Elongated, parallel microcavities of aeolian corrosion origin formed on the Åland rapakivi granite in Przyłanki (No. 43 in Fig. 1)
Równie sporą grupę (18 szt.) eratyków przewodnich stanowią granity Småland o wychodniach w płd.-wsch. Szwecji (nr 2 na ryc. 4). Ten rodzaj narzutniaka przewodniego znaleziono np. na polu w okolicach Korytna (nr 25), gdzie znajduje się, jako jedyny na obszarze badań, w pozycji in situ. Górna część tego głazu wystaje jedynie kilka centymetrów ponad powierzchnię terenu, stąd jego odnalezienie było możliwe wyłącznie dzięki wskazówkom gospodarza. Granity Småland występują ponadto w stanowiskach nr: 2, 4, 10, 17, 30, 31, 34, 35, 39, 42, 45, 49, 55, 64, 65, 68 i 74 .

Podczas badań zidentyfikowano 9 piaskowców Kalmarsund o wychodniach w Cieśninie Kalmarsund w południowo-wschodniej Szwecji (nr 3 na ryc. 4) oraz 3 granity z obszaru źródłowego Blekinge z południowej Szwecji (nr 4 na ryc. 4). Ponadto, wśród badanych 74 narzutniaków występuje 19 głazów skał magmowych i 7 głazów skał metamorficznych (gnejsów i granitognejsów) o bliżej nieokreślonym pochodzeniu.

Najczęściej badane głazy narzutowe mają wygładzone krawędzie, co jest dość powszechne i charakterystyczne dla wysokoenergetycznego środowiska transportu, np. w tunelach sub- lub inglacjalnych. Na dziesięciu głazach odnotowano przynajmniej na jednej powierzchni/ścianie występowanie wygładu lodowcowego. Taką wygładzoną powierzchnię zaobserwowano na pięciu granitach Småland: w Ochotniku (nr 4), Majstrach (nr 10), Przyłankach (nr 34), Wierzbowcu (nr 49) oraz w Policzku (nr 68). Wygładzona w efekcie detersji ścianę zidentyfikowano również na alandzkim granicie rapakivi w Policzku (nr 69), na największym w pryzmie w Ludwikowie okazie - piaskowcu Kalmarsund (nr 27; ryc. 7) i na trzech innych, nieprzewodnich granitach (nr 12, 62, 63). Zapis procesów subglacjalnych, których efektem są rysy polodowcowe, jest najlepiej widoczny na alandzkim granicie rapakivi w Policzku (nr 70) oraz na obtoczonych, drobnokrystalicznych granitach w Przyłankach (nr 40) i w Gaju Policzko (nr 73).

$\mathrm{Na}$ powierzchni badanych narzutniaków zaobserwowano ponadto ślady oddziaływania środowiska peryglacjalnego, kiedy głazy zostały uwolnione z topniejącego lądolodu i znalazły się na jego przedpolu. Na głazie narzutowym z Przyłanek (nr 4) widoczne są mikroformy rzeźby korazyjnej w postaci równoległych bruzd rozwiniętych tu na powierzchni plagioklazów. Mikrojamki (wnęki), o podobnej genezie, są także obecne na drobnokrystalicznym granicie leżącym w brzozowym lesie na Sokolej Górze

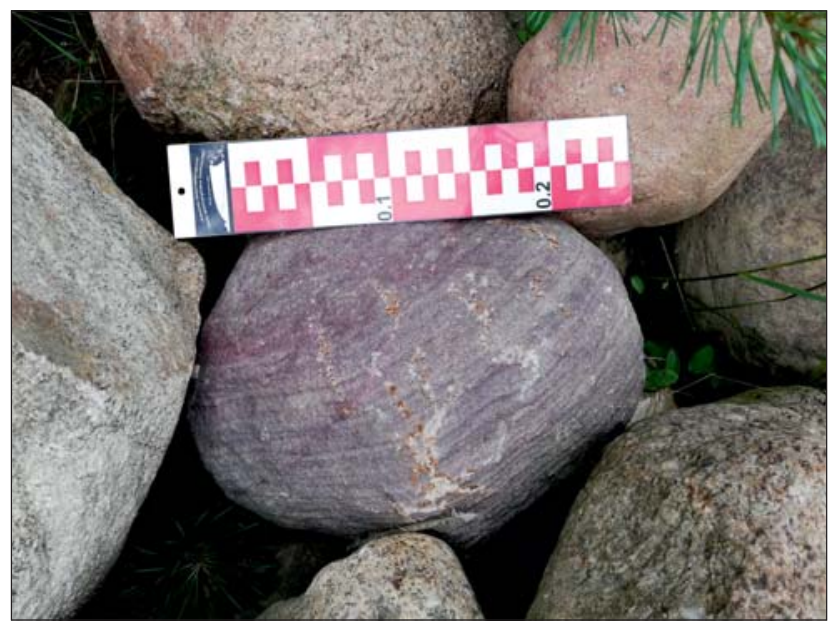

Ryc. 7. Piaskowiec Kalmarsund, Ludwików (nr 27 na ryc. 1) Fig. 7. Kalmarsund Sandstone, Ludwików (No. 27 in Fig. 1) 
(nr 60). Tej samej genezy rzeźbę, tym razem w postaci doskonale wykształconych żeber korazyjnych, na przemian $\mathrm{z}$ bruzdami, można dostrzec na powierzchni granitu ze Småland (nr 49; ryc. 6 - patrz str. 73), leżącym na skraju lasu w Wierzbowcu, oraz na grubokrystalicznym granicie z żyłą pegmatytową na Sokolej Górze, przy drodze do Pratkowic (nr 61).

Eolizację eksponowanych fragmentów skały zarejestrowano ponadto na wspomnianym już granicie Småland (nr 74) w Dobromierzu. Zarys grani, niewykształconego w pełni graniaka, jest widoczny na stosunkowo dużym (obw. 4,75 m) granicie Småland (nr 4) w Ochotniku przy skrzyżowaniu lokalnych dróg. Równie słabo wykształcony zarys grani oraz mikrożebra korazyjne można zauważyć na nieco mniejszym (obw. 4,15 m) granicie Småland (nr 68) przy nowej drodze w Policzku.

Współczesne procesy rzeźbiące powierzchnię badanych obiektów w postaci eksfoliacji, najczęściej górnej partii skały, zaobserwowano na głazach narzutowych Småland w Przyłankach (nr 34) i trzech na Kokosiej Górze (nr 17, 30 - ryc. 9 - patrz str. 73, i 31) oraz na powierzchni bardzo dobrze obtoczonego granitu w Majstrach (nr 23).

Znaczne ilości głazów narzutowych są zgromadzone (podczas oczyszczania pola lub terenu) w pryzmach, które występują w okolicy Majstrów (nr 9, 24 na ryc. 1), na Kokosiej Górze (nr 15-17, 29, 32 na ryc. 1; ryc. 11), w Korytnie (nr 18 i 19), na Majowej Górze (nr 20-22) oraz w Ludwikowie (nr 27).

Uwagę zwraca pryzma głazów narzutowych oznaczona nr 18 (w Korytnie), która ma największe rozmiary na obszarze badań. Ma ona długość co najmniej $42 \mathrm{~m}$, szerokość ok. 5 m i wysokość ponad 2 m (ryc. 12). Dostęp do niej jest utrudniony z uwagi na rozrastającą się roślinność.

W niewielkiej pryzmie w Ludwikowie (nr 27) zidentyfikowano kilka narzutniaków przewodnich: dwa piaskowce Kalmarsund (ryc. 7) oraz alandzkie granity rapakivi z charakterystycznymi owoidami skaleniowymi (Czubla i in., 2006; Górska-Zabielska, 2008). Na największym z nich występuje wygład lodowcowy. W pryzmie na Kokosiej Górze (nr 29) zidentyfikowano pięć alandzkich granitów rapakivi i pięć piaskowców Kalmarsund. Na powierzchni znajdującego się w sąsiedniej pryzmie granitu Småland (nr 30 na ryc. 1) zaobserwowano niszczenie powierzchniowej warstwy skały w następstwie eksfoliacji (ryc. 9 - patrz str. 73).

W pryzmie głazów narzutowych zgromadzonych na Majowej Górze (nr 20 na ryc. 1) zaobserwowano trzy piaskowce Kalmarsund, na których dostrzeżono ślady eolizacji w postaci wygładzonej powierzchni skał.

Spośród wszystkich 74 zewidencjonowanych głazów narzutowych w okolicach Przedborza 35 okazów waży tonę i więcej (dane szacunkowe). Takim głazem jest np. granit z żyłą pegmatytową, leżący na skraju lasu w Pratkowicach (nr 63 na ryc. 1; ryc. 10 - patrz str. 73). Jego szacunkowa waga wynosi 5,18 t (tab. 1). Jest to najcięższy i największy (obj. 1,88 $\mathrm{m}^{3}$ ) głaz narzutowy wśród zbadanych w okolicach Przedborza. Na jego powierzchni zaobserwowano rzeźbę korazyjną oraz na jednej ze ścian wygład lodowcowy. Nieco mniejszym głazem jest zwietrzałe alandzkie rapakivi w Policzku (nr 70; ryc. 8 - patrz str. 73) ze wspomnianymi wcześniej dobrze widocznymi rysami polodowcowymi. Wyliczony ciężar to $4,57 \mathrm{t}$. Powyżej $3 \mathrm{t}$ ważą dwa głazy narzutowe na Kokosiej Górze (nr 30): granit z Blekinge - regionu źródłowego w płd. Szwecji (waga $3,55 \mathrm{t})$, i granit Småland $(3,02 \mathrm{t}) \mathrm{z}$ rozwijającą się eksfolia- cją na górnej powierzchni skały, oraz jeden głaz - granitognejs w Wierzbowcu (nr 28; 3,04 t). Obwód każdego z wymienionych głazów wynosi $6 \mathrm{~m}$ i więcej.

Zaledwie dwa głazy narzutowe (nr 33 i 74 na ryc. 1) pełnią dziś rolę kulturotwórczą, bo współtworzą obiekty, mające, poprzez okolicznościowe tablice upamiętniające bohaterskie czyny strażaków z Dobromierza i Przedborza, oddziaływać na lokalną społeczność. Tę samą funkcję pełni przedborska golgota przy kościele pw. św. Aleksego, zbudowana z okolicznych głazów narzutowych. Ilość skał zużytych do wzniesienia tego wielkopowierzchniowego sakralnego obiektu dobitnie świadczy, że region Przedborza obfituje w skandynawski materiał narzutowy.

Badania Urbana (1990, 1997), Stoińskiego (1997), Pernala (2004, 2005), Kusztala (2016) i autorki (Górska-Zabielska i in., 2019a, b), przeprowadzone w regionie północno-zachodniego obrzeżenia Gór Świętokrzyskich, dokumentują regiony zwiększonej obecności głazów narzutowych. Są to okolice Kamiennej Woli, Radoszyc, Mnina i Ostrych Górek, ok. $3 \mathrm{~km}$ na zachód od Czarnieckiej Góry, w rejonie doliny Czarnej Koneckiej. Występowanie głazów narzutowych w Mniowie i Ostrych Górkach, należy wiązać z postojem czoła lądolodu na linii zasięgu podczas MIS 6. Zarówno Lindner (np. 1971), jak i Kwapisz $\mathrm{i}$ in. (2015) lokują Ostre Górki na wzgórzu moreny czołowej z okresu maksymalnego zasięgu lądolodu środkowopolskiego. Zarówno na zapleczu (badania R. Zabielskiego w ramach SMGP, 2021), jak i na przedpolu strefy glacjomarginalnej (badania M. Górskiej-Zabielskiej) nie zaobserwowano wyraźnie zwiększonej liczebności głazów narzutowych. Innym regionem charakteryzującym się dużą populacją głazów narzutowych są porośnięte lasem okolice Lemierzy, $10 \mathrm{~km}$ na płn.-wsch. od Ostrowa Świętokrzyskiego (dr E. Gałka, AGH, inf. ust., 2016). Znajdują się one w strefie glacjomarginalnej lądolodu związanego z MIS 6 .

\section{PODSUMOWANIE}

W świetle przeprowadzonych badań należy stwierdzić, że dzisiejszy obraz rozmieszczenia oraz liczba głazów narzutowych w okolicach Przedborza (ryc. 2) różni się zasadniczo od tego, jaki przedstawili Czernicka-Chodkowska (1977, 1980, 1983; ryc. 3) i Kwapisz (1983). Czernicka-Chodkowska zinwentaryzowała zaledwie ok. 20 głazów (ryc. 3), a Kwapisz (1983) więcej, ale głównie w środkowej i północnej części obszaru arkusza Przedbórz.

W następstwie działalności antropogenicznej, głównie rolniczej, ale także budowy sieci wodociągowo-kanalizacyjnej i drogowej, na powierzchnię terenu wydobyto z podłoża dużo głazów narzutowych. Poza jednym głazem narzutowym in situ, znajdującym się w obrębie gospodarstwa rolnego w Korytnie (nr 25), pozostałe zewidencjonowane głazy występują w pozycji ex situ. Ponieważ pochodzą głównie z okolicznych pól, to ich dzisiejsza pozycja niewiele różni się od oryginalnej, sięgającej czasów depozycji glacjalnej. Jest ich to ich największy walor naukowy, który pozwala wykorzystać badane głazy w odtworzeniu kierunków dalekiego transportu z Wysp Alandzkich, regionu Småland w płd.-wsch. Szwecji, Cieśniny Kalmarsund i Blekinge w płd. Szwecji (ryc. 4).

Badane głazy noszą na swojej powierzchni ślady świadczące o charakterystycznym klimacie peryglacjalnym, który panował na przedpolu topniejącego lądolodu stadiału warty zlodowacenia odry z kompleksu środkowopolskiego. Charakterystyczne mikroformy, jakie można dziś dostrzec 


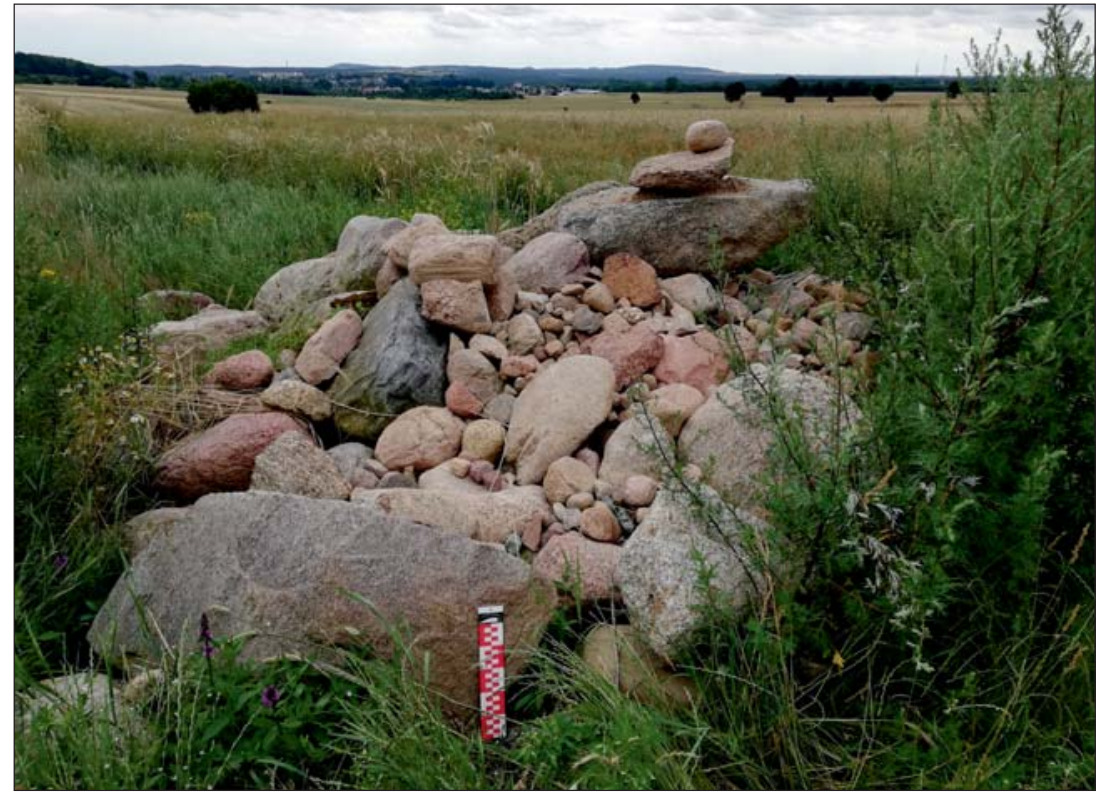

Ryc. 11. Pryzma głazów narzutowych (nr 32 na ryc. 1) przy drodze polnej na Kokosiej Górze. Widok w kierunku południowo-wschodnim

Fig. 11. A prism of erratic boulders (No. 32 in Fig. 1) by a dirt road in Kokosia Góra. View towards the south-east

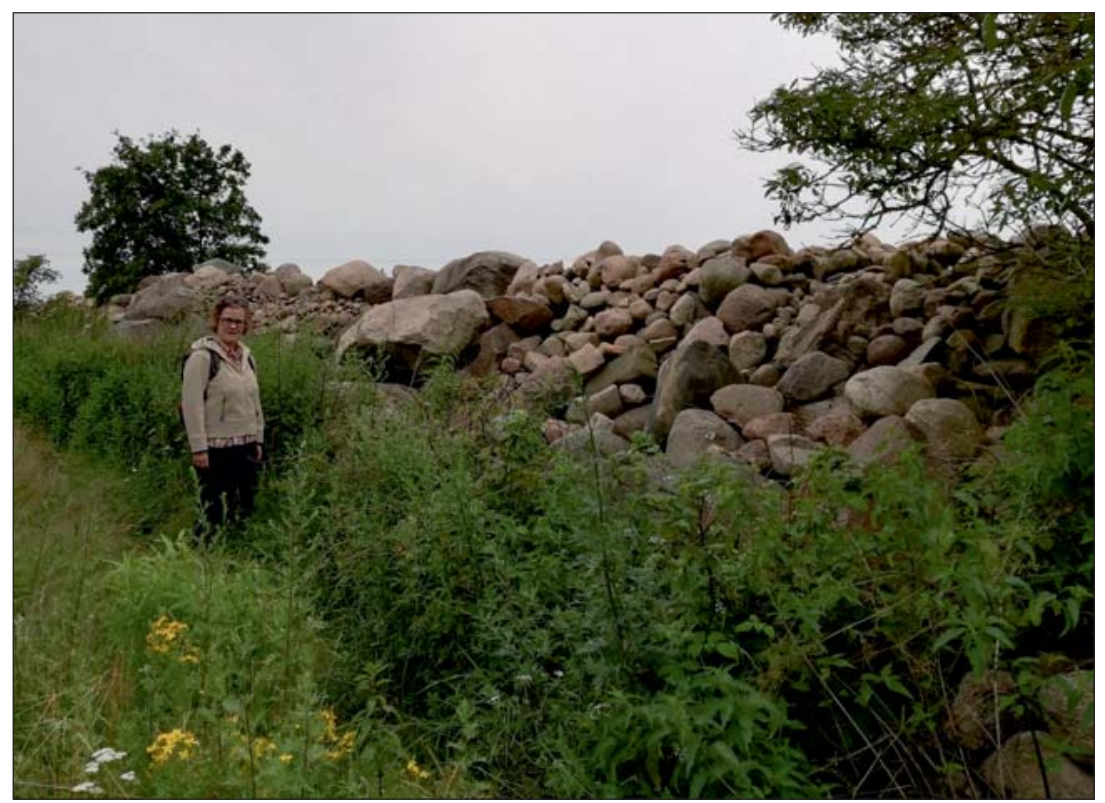

Ryc. 12. Największa zinwentaryzowana pryzma głazów narzutowych w Korytnie (nr 18 na ryc. 1) ma długość co najmniej $42 \mathrm{~m}$. Fot. D. Wieczorek

Fig. 12. The largest inventoried prism of erratic boulders in Korytno (No. 18 in Fig. 1) is at least $42 \mathrm{~m}$ long. Photo by D. Wieczorek

na powierzchni wielu głazów narzutowych, świadczą o istnieniu wtedy suchego i mroźnego klimatu peryglacjalnego.

Nie mniej ważnym walorem poznawczym jest wiek depozycji badanych głazów narzutowych. Zostały one wydobyte $z$ przypowierzchniowej warstwy osadów lodowcowych zdeponowanych podczas MIS 6, a więc można domniemywać, że zostały osadzone w czasie stadiału warty zlodowacenia odry (np. Wachecka-Kotkowska i in., 2013; Wachecka-Kotkowska, 2015a). Wśród głazów znajdujących się współcześnie na powierzchni (lub w osadach podłoża) obszaru badań mogą znaleźć się także te redeponowane. Były one transportowane w czasie wcześniejszych nasunięć lądolodu skandynawskiego. Niestety jak dotąd nie opracowano metody odróż- niania obu grup narzutniaków.
Poza znaczeniem naukowym, głazy narzutowe w ostatnich latach pełnią także rolę edukacyjną (np. Górska-Zabielska, Zabielski, 2018), która zyskuje na znaczeniu wraz z ich lepszą dostępnością. Im głazy są zlokalizowane bliżej szkoły, tym to znaczenie wzrasta (Górska-Zabielska, 2020, 2021a). Stosunkowo niewielka odległość badanych głazów od szkół w Przedborzu i okolicy pozwala mieć nadzieję, że nauczyciele geografii i innych przedmiotów, wyposażeni w odpowiednie publikacje dydaktyczne i scenariusze lekcji oraz posiłkując się ustawionymi w przyszłości tablicami informacyjnymi, zechca skorzystać $\mathrm{z}$ tych podręcznych środków dydaktycznych. Obowiązkowe i o wiele bardziej atrakcyjne lekcje poza budynkiem szkolnym należą do szkolnego kanonu podstawy programowej (Dobosik, 2013; Moskwa, Miraj, 2018; Roca, Garcia-Valles, 2020). Oglądając głazy narzutowe, uczeń przede wszystkim pozna podstawowe typy petrograficzne skał oraz nauczy się rozpoznawać efekty erozji, transportu i depozycji glacjalnej, pozna kierunki dalekiego transportu głazów narzutowych ze skandynawskich wychodni po okolice Przedborza. Poprzez identyfikację innych elementów środowiska abiotycznego dowie się on czym jest jego georóżnorodność (np. Kostrzewski, 1998; Kozłowski i in., 2004; Zwoliński i in., 2018). Te komponenty edukacyjne moga $\mathrm{z}$ powodzeniem zostać wykorzystane również w nowoutworzonych ścieżkach/szlakach edukacyjnych czy w takich innowacjach jak np. Turystyczno-Rekreacyjne Imprezy na Orientację (TRInO; http://trino.pttk.pl/). Sa to wydarzenia z mapa i/lub kompasem, których głównym celem jest turystyczno-rekreacyjne spędzenie czasu, poznanie walorów turystyczno-krajoznawczych różnych zakątków Polski. TRInO jest przeznaczone dla turystów pieszych i rowerzystów. W obszarach peryferyjnych turystycznie, zlokalizowanych z dala od dużych ośrodków kulturowych i centrów turystycznych, takie pionierskie szlaki penetracji linearnej (Styperek, 2002) mogą stać się kołem zamachowym lokalnej geoturystyki (np. Górska-Zabielska, Dobracki, 2015; Ateş, Ateş, 2019).

Nie bez znaczenia sa wszelkie działania majace na celu promocję georóżnorodności jako ważnej części naturalnego dziedzictwa przyrodniczego (np. Wolniewicz, 2021). Zdaniem Kubalikovej i in. (2021) mogą one prowadzić do lepszej akceptacji proponowanych działań w zakresie terytorialnej i ogólnej ochrony przyrody i krajobrazu, w tym ochrony elementów i zjawisk geologicznych. W konsekwencji większa świadomość społeczna o potrzebie geokonserwacji przełoży się na skuteczniejsze planowanie i adekwatne zapisy w dokumentach strategicznych lokalnego samorządu. 
Podsumowując, badane głazy narzutowe stanowią ważny element georóżnorodności, w omawianym przypadku okolic Przedborza, świadczą o działalności lądolodu, szczególnie w jego strefie glacjomarginalnej podczas MIS 6. Sa one dziedzictwem geologicznym regionu i pełnią dziś funkcję naukową i poznawczą. W świetle przytoczonych przykładów posiadają duży potencjał rozwoju geoturystyki. Bezkonfliktowe środowiskowo wykorzystanie naturalnych walorów obszaru w lokalnej polityce zrównoważonego rozwoju społecznego i ekonomicznego (McKeever, Zouros, 2005; Dobracki, 2008; Burlando i in., 2011; Brilha i in., 2018; Ateş, Ateş, 2019; Frey, 2021) może się przyczynić do ochrony dziedzictwa geologicznego. A poprzez efektywne zabezpieczenie geostanowisk, szeroką promocję nauk geologicznych oraz propagowanie ich funkcji edukacyjnych (np. Wolniewicz, 2019, 2021) i turystycznych (np. Farsani i in., 2017) może wpłynąć na polepszenie sytuacji ekonomicznej gospodarzy tego regionu.

Dziękujemy dr. K. Tylmannowi, anonimowemu Recenzentowi oraz redaktorowi naczelnemu Przegladu Geologicznego dr. hab. W. Treli za wnikliwe uwagi i wartościowe sugestie. Badania Marii Górskiej-Zabielskiej zostały sfinanowane z minigrantu UJK nr 21/2019DKPK/008/04/2019 i SMGR.RN.20.228.634.

\section{LITERATURA}

AGER D.V. 1980 - The geology of Europe. McGraw Hill, London. ANDRÉASSON P.G., RODHE A. 1990 - Geology of the Protogine Zone south of the Lake Vaettern, southern Sweden: a reinterpretation. Geol. Fören. Stockh. Förh., 112 (2): 107-125.

ATEŞ H.Ç., ATEŞ Y. 2019 - Geotourism and Rural Tourism Synergy for Sustainable Development-Marçik Valley Case-Tunceli, Turkey. Geoheritage, 11: 207-215.

BOGDANOVA S., BINGEN B., GORBATSCHEV R., KHERASKOVA T.N., KOZLOV V.I., PUCHOV V.N., VOLOZH Y.A. 2008 - The Eas European Craton (Baltica) before and during the assembly of Rodinia. Precambr. Res., 160: 23-45.

BRILHA J., GRAY M., PEREIRA D.I., PEREIRA P. 2018 - Geodiversity: an integrative review as a contribution to the sustainable management of the whole of nature. Environ. Sci. Policy, 86: 19-28.

BURLANDO M., FIRPO M., QUEIROLO C., ROVERE A., VACCHI M.

2011 - From geoheritage to sustainable development: Strategies and perspectives in the Beigua Geopark (Italy). Geoheritage, 3: 63-72.

CABAJ W. 1981 - Deglacjacja północnej części Niecki Nidziańskiej w czasie zlodowacenia środkowopolskiego. Folia Geogr., Ser. Geogr.-Phys., 14: 103-120.

CIEŚLIŃSKI S. 1956 - Stratygrafia i tektonika kredy miedzy Dobromierzem i Józefowem a Przedborzem nad Pilicą. Biul. Inst. Geol., 113.

COCKS L.R.M., TORSVIK T.H. 2005 - Baltica from late Precambrian to mid-Palaeozoic times: the gain and loss of a terrane's identity. Earth Sci. Rev., 72: 39-66.

CORATZA P., REYNARD E., ZWOLIŃSKI Z. 2018 - Geodiversity and Geoheritage: Crossing Disciplines and Approaches. Geoheritage, 10: 525-526.

CZERNICKA-CHODKOWSKA D. 1977 - Zabytkowe głazy narzutowe na obszarze Polski. Katalog cz. I i II. Wyd. Geol., Warszawa.

CZERNICKA-CHODKOWSKA D. 1980 - Zabytkowe głazy narzutowe na obszarze Polski. Część III, Polska południowo-wschodnia i południowa. Wyd. Geol., Warszawa.

CZERNICKA-CHODKOWSKA D. 1983 - Zabytkowe głazy narzutowe na obszarze Polski. Część IV, Polska północna, środkowa i południowo-zachodnia. Głazy Warszawy. Wyd. Geol., Warszawa.

CZUBLA P. 1988 - Tektonika elewacji radomszczańskiej na podstawie metod mezostrukturalnych. Prz. Geol., 36 (10): 560-566.

CZUBLA P., GAŁĄZKA D., GÓRSKA M. 2006 - Eratyki przewodnie W glinach morenowych Polski. Prz. Geol., 54 (4): 352-362.

DOBOSIK B. 2013 - Zadania dydaktyczne i scenariusze zajęć terenowych dla nauczycieli prowadzących edukację przyrodniczą na terenie ścieżki „Kopalnia przywrócona naturze” w kamieniołomie „Lipówka” w Rudnikach. [W:] Śliwińska-Wyrzychowska A. (red.), Lipówka kopalnia przywrócona naturze. Akademia im. Jana Długosza w Częstochowie.
DOBRACKI R. 2008 - Projekt utworzenia geoparku Pojezierza Drawskiego. [W:] Jasnowska J. (red.), Spotkanie z nauką w Połczynie Zdroju, Barwicach i Czaplinku. IX Zachodniopomorski Festiwal Nauki, Szczecin-Połczyn Zdrój: 15-23.

DOWLING R.K., NEWSOME D. 2005 - Geotourism's issues and challenges. [W:] Dowling R., Newsome D. (red.), Geotourism. Elsevier Butterworth-Heinemann, Oxford: 242-254.

DURAJ M., NIEMIEC D., CHENG X., KOLEŇÁK P. 2017 - Vestiges of glacial action in Ostrava: their significance for an application in geotourism. World Multidisciplinary Earth Sciences Symposium (WMESS), IOP Conf. Series: Earth and Environmental Science 95. https://doi.org/10.1088/1755- 1315/95/5/052014

FARSANI N.T., COELHO C., COSTA C., DE CARVALHO C.N. 2012 Geoparks and Geotourism: New Approaches to Sustainability for the st Century. Brown Walker Press, Boca Raton, USA.

FARSANI N.T., MORTAZAVI M., BAHRAMI A., KALANTARY R., BIZHAEM F.K. 2017 - Traditional crafts: a tool for geo-education in geotourism. Geoheritage, 9 (4): 577-584.

FREDÉN C. 1994 - National Atlas of Sweden: geology. National Committee of Geography under the auspices of the Royal Swedish Academy of Sciences. Almquist \& Wiksell International, Stockholm.

FREY M.-L. 2021 - Geotourism-Examining Tools for Sustainable Development. Geosciences 11 (30), https://doi.org/10.3390/geosciences11010030

GAÁL G., GORBATSCHEV R. 1987 - An outline of the Precambrian evolution of the Baltic Shield. Precambr. Res., 35: 15-52.

GORBATSCHEV R. 1980 - The Precambrian development of southern Sweden. Geol. Fören. Stockh. Förh., 102: 129-136.

GORBATSCHEV R. 1985 - Precambrian basement of the Scandinavian Caledonides. [W:] Gee D.G., Sturt B.A. (red.), The Caledonide orogeny-Scandinavia and related areas. Wiley, Chichester: 197-212.

GÓRSKA-ZABIELSKA M. 2008 - Obszary macierzyste skandynawskich eratyków przewodnich osadów ostatniego zlodowacenia północno-zachodniej Polski i północno-wschodnich Niemiec. Geologos, 14 (2): 177-194

GÓRSKA-ZABIELSKA M. 2010 - Głazy narzutowe w Wielkopolsce. Prace i Studia z Geografii i Geologii, t. 18. Bogucki Wyd. Naukowe.

GÓRSKA-ZABIELSKA M. 2015 - Najcenniejsze głazy narzutowe w Wielkopolsce i ich potencjał geoturystyczny. Prz. Geol., 63 (8): 455-463.

GÓRSKA-ZABIELSKA M. 2019 - Obszary macierzyste głazów narzutowych w kontekście rzeźby regionu świętokrzyskiego. [W:] Urban J. (red.), VII Warsztaty geomorfologii strukturalnej. Rzeźba strukturalna Gór Świętokrzyskich i Ponidzia - stan badań i perspektywy badawcze. Streszczenia referatów i posterów, przewodnik sesji terenowych: 18-19. GÓRSKA-ZABIELSKA M. 2020 - Nowe obiekty geoturystyczne na południowym Podlasiu. Prz. Geol., 68 (2): 91-99.

GÓRSKA-ZABIELSKA M. 2021a - The Rock Garden of the Institute of Geography and Environmental Sciences, Jan Kochanowski University - a new geo-site in Kielce, Central Poland. Geosciences, 11 (3), https://doi.org/10.3390/geosciences 11030113

GÓRSKA-ZABIELSKA M. 2021b (w druku) - In the footsteps of the ice sheet in the area of the planned geopark Postglacial land of the Drawa and Dębnica rivers (Pomerania, Poland). Landform Analysis.

GÓRSKA-ZABIELSKA M., DOBRACKI R. 2015 - Petrographic Garden in Moryń - a new geotouristic attraction in western Poland. Landform Analysis, 29: 73-80.

GÓRSKA-ZABIELSKA M., KUSZTAL P., WITKOWSKA K. 2019 Wybrane głazy narzutowe północno-zachodniego obrzeżenia Gór Świętokrzyskich - współczesne znaczenie i potencjał geoturystyczny (Wyżyna Przedborska i Kielecka). Prz. Geol., 67 (9): 767-774.

GÓRSKA-ZABIELSKA, M., WITKOWSKA, K., PISARSKA, M., MUSIAŁ R., JOŃCA B. 2020 - The Selected Erratic Boulders in the Świętokrzyskie Province (Central Poland) and Their Potential to Promote Geotourism. Geoheritage, 12 (30): 1-14.

GÓRSKA-ZABIELSKA M., ZABIELSKI R. 2018 - Geotourism Development in an Urban Area based on the Local Geological Heritage (Pruszków, Central Mazovia, Poland). [W:] Thornbush M.J., Allen C.D. (red.), Urban Geomorphology. Landforms and Processes in Cities, Elsevier: 37-54.

GRAY M. 2004 - Geodiversity: Valuing and Conserving Abiotic Nature. Chichester, U.K.: JohnWiley \& Sons.

GRAY M. 2005 - Geodiversity and Geoconservation: What, Why, and How? [W:] Santucci V.L. (red.), Geodiversity \& Geoconservation, 22 (3): 4-11.

GRAY M. 2013 - Geodiversity: valuing and conserving abiotic nature, second edn. Wiley Blackwell, Chichester. 
GRAY M. 2018 - Geodiversity: the backbone of geoheritage and geoconservation. [W:] Reynard E., Brilha J. (red.), Geoheritage: assessment, protection, and management. Elsevier, Amsterdam: 13-25.

HÖLLTÄ P., BALAGANSKY V., GARDE A.A., MERTANEN S., PELTONEN P., SLABUNOV A., SORJONEN-WARD P., WHITEHOUSE M. 2008 - Archean of Greenland and Fennoscandia. Episodes, 31 (1) 13-19.

HOSE T.A. 2005 - Geotourism and interpretation. [W:] Dowling R., Newsome D. (red.), Geotourism. Elsevier Butterworth-Heinemann, Oxford: 221-241

HOSE T.A. 2012 - 3G's for modern geotourism. Geoheritage, 4: 7-24. IVY-OCHS S., KOBER F. 2008 - Surface exposure dating with cosmogenic nuclides. Eiszeitalt. Ggw. Quatern. Sci. J., 57: 179-209.

http://www.sp6.pruszkow.pl/index.php?option=com_content\&task=view\&id=1406\&Itemid $=30$

http://trino.pttk.pl/

JURKIEWICZOWA I. 1965 - Szczegółowa Mapa Geologiczna Polsk w skali $1: 50$ 000, ark. Czermno (M34-29C). Wydaw. Geol, Warszawa. JURKIEWICZOWA I. 1968 - Objaśnienia do Szczegółowej Mapy Geologicznej Polski w skali 1: 50 000, ark. Czermno (M34-29C). Wydaw. Geol., Warszawa.

KASPRZAK L. 2003 - Model sedymentacji lądolodu vistuliańskiego na Nizinie Wielkopolskiej. Wydaw.Nauk. UAM.

KEITER M. 2017 - Die „Großen Sieben” und der neue Findlingsgarten in Bielefeld-Botschafter vom saalezeitlichen Eisrand. Geschiebekd. Aktuell 33: 119-129.

KIRILLOVA K.S., FU X., LEHTO X., LIPING CAI L. 2014 - What makes a destination beautiful? Dimensions of tourist aesthetic judgment Tourism Management, 42: 282-293.

KIRILLOVA KS., LEHTO X. 2015 - Destination Aesthetics and Aesthetic Distance in Tourism Experience. Journal of Travel \& Tourism Marketing, 32 (8); https://doi.org/10.1080/10548408.2014.958608

KOSTRZEWSKI A. 1998 - Georóżnorodność rzeźby jako przedmio badań geomorfologii. [W:] Pękala K. (red.), „Główne kierunki badań geomorfologicznych w Polsce. Stan aktualny i perspektywy". IV Zjazd Geomorfologów Polskich, Lublin, 3-6.06.1998, Referaty i komunikaty, Wydaw. UMCS, Lublin: 11-16.

KOZŁOWSKI S., MIGASZEWSKI Z., GAŁUSZKA A. 2004 - Znaczenie georóżnorodności w holistycznej wizji przyrody. Prz. Geol., 52 (4): 291-294.

KUBALÍKOVÁ L., BAJER A., BALKOVÁ M. 2021 —Brief Notes on Geodiversity and Geoheritage Perception by Lay Public. Geosciences, 11 (2); https://doi.org/10.3390/geosciences11020054

KUTEK J. 1968 - Kimeryd i najwyższy oksford południowo-zachodniego obrzeżenia mezozoicznego Gór Świętokrzyskich. Część I. Stratygrafia. Acta Geol. Pol., 18 (3): 493-586.

KUSZTAL P. 2016 - Budowa geologiczna i rzeźba doliny Czarne Koneckiej pomiędzy Janowem a Wąsoszem Starą Wsią. Praca magisterska, Inst. Geogr. UJK, Kielce.

KWAPISZ B. 1983 - Szczegółowa Mapa Geologiczna Polski w skali 1:50 000, ark. Przedbórz (775) wraz z objaśnieniami. Wydaw. Geol. Warszawa.

KWAPISZ B., MADRY S., POPIELSKI W. 2015 - Szczegółowa Mapa Geologiczna Polski w skali 1 : 50 000, ark. Radoszyce (zreamb. w latach 2007-2009 na podst. Jurkiewicz, 1967). Państw. Inst. Geol., Ministerstwo Środowiska, Warszawa.

LEWIŃSKI J. 1908 - Pasmo Przedborskie. Rozpr. Wydz. Mat.-Przyr Pol. Akad. Umiej., 48. Kraków.

LINDNER L. - 1971 - Stratygrafia plejstocenu i paleogeomorfologia północno-zachodniego obrzeżenia Gór Świętokrzyskich. Stud. Geol. Pol., 35: 1-113.

LINDNER L. 1977 - Zlodowacenie plejstoceńskie w zachodniej części Gór Świettokrzyskich. Stud. Geol. Pol., 53.

LINDNER L., MARKS L. 2012 - O podziale klimatostratygraficznym kompleksu środkowopolskiego w plejstocenie Polski. Prz. Geol., 60 (1): $36-45$.

LUNDQUIST T. 1979 - The Precambrian of Sweden. Sver. Geol. Unders., C768: 1-87.

LUNDQUIST T., BYGGHAMMAR B. 1994 - The bedrock. The Swedish Precambrian. [W:] Fredén C. (red.), National Atlas of Sweden: geology. National Committee of Geography under the auspices of the Royal Swedish Academy of Sciences. Almquist \& Wiksell International, Stockholm: $14-21$

LÜTTIG G. 1958 - Methodische Fragen der Geschiebeforschung. Geol. Jahrb., 75: 361-418.

MARKS L., DZIERŻEK J., JANISZEWSKI R., KACZOROWSKI J., LINDNER L., MAJECKA A., MAKOS M., SZYMANEK M., TOŁOCZKO-PASEK A., WORONKO B. 2016 - Quaternary stratigraphy and palaeogeography of Poland. Acta Geol. Pol., 66 (3): 403-427.
MCKEEVER P., ZOUROS N. 2005 - Geoparks: Celebrating Earth heritage, sustaining local communities. Episodes, 28: 274-278.

MEYER K.-D. 1983 - Indicator pebble and stone count methods. [W:] Ehlers J. (red.), Glacial deposits in North-West Europe. Balkema, Rotterdam: 275-287.

MEYER K.-D. 2006 - Der Findlingsgärten in Niedersachsen. Arch. Geschiebekd., 5: 323-338.

MEYER K.-D., LÜTTIG G. 2007 - Was meinen wir mit Leitgeschiebe? Geschiebekunde Aktuell, 23 (4): 106-121.

MIGOŃ P. 2012 - Geoturystyka. Wydaw. Nauk. PWN, Warszawa.

MIGOŃ P., RÓŻYCKA M. 2021 - When Individual Geosites Matter Less-Challenges to Communicate Landscape Evolution of a Complex Morphostructure (Orlické-Bystrzyckie Mountains Block, Czechia/Poland, Central Europe). Geosciences, 11, https://doi.org/10.3390/geosciences11020100

MOSKWA K., MIRAJ K. 2018 - Geotourism applied to the didactic and educational work of a geography teacher. Geotourism, 3-4 (54-55): 3-10.

PASSENDORFER E. 1939 - O triasie i dolnej jurze na pn.-zachodnich zboczach Gór Świętokrzyskich. Prace Tow. Przyjaciół Nauk w Wilnie, Wydz. Nauk Mat. i Przyr., t. 13, Prace Zakł. Geol., Uniw. Stefana Batorego w Wilnie, nr 9.

PERNAL J. 2004 - Pomniki przyrody woj. świętokrzyskiego. Głazy narzutowe. Cześć 1. Liga Ochr. Przyr., Kielce.

PERNAL J. 2005 - Pomniki przyrody woj. świętokrzyskiego. Głazy narzutowe. Cześć 2. Liga Ochr. Przyr., Kielce.

POŻARYSKI W. 1971 - Tektonika elewacji radomskowskiej. Rocz. Pol. Tow. Geol., 41 (1): 169-179.

REYNARD E. 2004 - Protecting stones: conservation of erratic blocks in Switzerland. [W:] Prikryl R. (red.), Dimension Stone. New perspectives for a traditional building material. Balkema, Leiden: 3-7.

RINTERKNECHT V., MARKS L., PIOTROWSKI J.A., RAISBECK G.M., YIOU F., BROOK E.J., CLARK P.U. 2005 - Cosmogenic 10Be ages on the Pomeranian Moraine, Poland. Boreas, 34: 186-191.

RINTERKNECHT V., BRAUCHER R., BÖSE M., BOURLÈS D., MERCIER J.-L. 2012 - Late Quaternary ice sheet extents in northeastern Germany inferred from surface exposure dating. Quatern. Sci. Rev., 44: $89-95$.

ROCA N., GARCIA-VALLES M. 2020 - Trainee Teacher Experience in Geoscience Education: Can We Do Better? Geoheritage, 12, https://doi.org/10.1007/s12371-020-00518-8

RUBAN D.A., SALLAM E.S., ERMOLAEV V.A., YASHALOVA N.N. 2020 - Aesthetic Value of Colluvial Blocks in Geosite-Based Tourist Destinations: Evidence from SW Russia. Geosciences 10 (2), 51, https://doi.org/10.3390/geosciences 10020051

SALA S. 2011 - Rzeźba krawędziowa północno-zachodniej części Pasma Przedborsko-Małogoskiego. [W:] Zieliński A. (red.) Znane fakty - nowe interpretacje w geologii i geomorfologii. Inst. Geogr. UJK, 65-77.

SAWICKI L. 1922 - Wiadomość o środkowopolskiej morenie czołowej. Rozpr. Wydz. Mat.-Przyr. PAU, ser. III, t. 21, dz. A.

SCHULZ W. 1996 - Zur Bedeutung der Korngröße bei Geschiebezählungen. Der Geschiebesammler, 29 (3): 91-102.

SCHULZ W. 1999 - Sedimentäre Findlinge im norddeutschen Vereisungsgebiet. Archiv für Geschiebekunde, 2 (8): 523-560.

SCHULZ W. 2003 - Geologischer Führer für den Norddeutschen Geschiebesammler; CW Verlagsgruppe: Schwerin, Germany.

SERRANO E., RUIZ-FLANO P., VALLADOLID 2007 - Geodiversity. A theoretical and applied concept. Geographica Helvetica, 62 (3): $140-147$.

STOIŃSKI A. 1997 - Głazy narzutowe w okolicy Radoszyc. Pr. magisterska, Arch. Inst. Geogr. WSP (obecnie UJK), Kielce.

STYPEREK J. 2002 - Linearne systemy penetracji rekreacyjnej. Bogucki Wyd. Nauk., Poznań.

ŚWIDZIŃSKI H. 1935 - Szkic geologiczny okolic Przedborza nad Pilicą. Spraw. Państw. Inst. Geol., 8 (3): 1-25.

TUULING I., FLODÉN T. 2001 - The structure and relief of the bedrock sequence in the Gotland-Hiiumaa area, northern Baltic Sea. GFF, 123: $35-49$.

TYLMANN K., RINTERKNECHT V.R., WOŹNIAK P.P., BOURLÈS D., SCHIMMELPFE-NNIG I., GUILLOU V., ASTER TEAM 2019 - The Local Last Glacial Maximum of the southern Scandinavian Ice Sheet front: Cosmogenic nuclide dating of erratics in northern Poland. Quatern. Sci. Rev., 219 (1): 36-46.

TYLMANN K., WOŹNIAK P.P., RINTERKNECHT V. 2017 - Analiza przydatności eratyków Pomorza w badaniach chronologii recesji ostatniego lądolodu skandynawskiego metodą izotopów kosmogenicznych. Acta Geogr. Lodz., 106: 181-194. 
URBAN J. 1990 - Protection of inanimate nature objects in the Góry Świętokrzyskie (Holy Cross Mts) province. Rocz. Świętokrzyski, 17: 47-79.

URBAN J. 1997 - Geologia i rzeźba obszaru badań. [W:] Zając T. (red.), Waloryzacja przyrodnicza Szanieckiego Parku Krajobrazowego. Arch. Inst. Ochr. Przyr. PAN, Kraków.

URBAN J., MIGOŃ P., RADWANEK-BĄK B. 2021 - Dziedzictwo geologiczne. Prz. Geol., 69 (1): 16-20.

VINX R. 2015 - Gesteinsbestimmung im Gelände. Springer, Berlin Heidelberg.

WACHECKA-KOTKOWSKA L. 2013 - Budowa geologiczna form glacimarginalnych na Wyżynie Przedborskiej - przykładowe studia. Biul. Państw. Inst. Geol., 454: 103-120.

WACHECKA-KOTKOWSKA L. 2015a - Rozwój rzeźby obszaru miedzy Piotrkowem Trybunalskim, Radosmkiem a Przedborzem w czwartorzędzie. Wyd. UŁ.

WACHECKA-KOTKOWSKA L. 2015b - Badania ułożenia klastów w glinach morenowych jako element rekonstrukcji kierunków transportu lodowego w obszarze miedzy Piotrkowem Trybunalskim, Radomskiem a Przedborzem. Acta Geogr. Lodz., 103: 99-111.

WACHECKA-KOTKOWSKA L., CZUBLA P., GÓRSKA-ZABIELSKA M., KROL E., BARCZUK A. 2013 - Wiek stref glacimarginalnych SE części regionu łódzkiego. [W:] VI Seminarium Geneza, litologia, stratygrafia utworów czwartorzędowych, 14-15 listopada 2013 r., Poznań

WACHECKA-KOTKOWSKA L., CZUBLA P., RYCHEL J., MORAWSKI M., GÓRSKA-ZABIELSKA M., KRÓL E. 2017b - Stanowisko Ochotnik i Masłowice. Przekształcenia peryglacjalne glin warciańskich na południowym stoku Bąkowej Góry. [W:] XXIV Konferencja Stratygrafia Plejstocenu Polski, Wawrzkowizna k. Bełchatowa, 4-8.09.2017 r.: 169-173.

WACHECKA-KOTKOWSKA L., GÓRSKA-ZABIELSKA M. 2010 Cechy petrograficzne osadów glacigenicznych budujących powierzchnię Wysoczyzny Bełchatowskiej, Równiny Piotrkowskiej i Wzgórz Radomszczańskich - wyniki wstępne. [W:] Marks L., Pochocka-Szwarc K. (red.), XVII Konf. Stratygrafia Plejstocenu Polski, Jeziorowskie, 6-10.09.2010 r. Państw. Ins. Geol., Warszawa: 58-63.

WACHECKA-KOTKOWSKA L., STEPIEŃ B., GÓRSKA-ZABIEL-

SKA M., KRÓL E. 2017a - Stanowisko Miejskie Pola. Pagórek moreny czołowej czy pagórek kemowy? Warciańska strefa marginalna w otoczeniu wzgórz ostańcowych Pasma Przedborsko-Małogoskiego. [W:] XXIV Konferencja Stratygrafia Plejstocenu Polski, Wawrzkowizna k. Bełchatowa, 4-8.09.2017 r.: 165-168.

WARTOŁOWSKA-ŚWIDROWSKA J. 1976 - Analiza strukturalna brachyantykliny Dobromierza (południowo-zachodnie obrzeżenie Gór świętokrzyskich). Kwart. Geol., 20, 4.

WĄGROWSKI A. 1986 - Szczegółowa Mapa Geologiczna Polski w skali $1: 50$ 000, ark. Rzejowice (774). Wyd. Geol., Warszawa.

WA_GROWSKI A. 1987 - Objaśnienia do Szczegółowej Mapy Geologicznej Polski w skali 1 : 50 000, ark. Rzejowice (774). Wyd. Geol., Warszawa.

WENTWORTH C.K.A. 1922 - A scale of grade and class terms for clastic sediments. J. Geol., 30: 377-392.

WIECZOREK D., STOIŃSKI A., ZABIELSKI R. 2020a - Objaśnienia do Szczegółowej Mapy Geologicznej Polski w skali 1 : 50 000, ark. Przedbórz (775). Aktualizacja. Państw. Inst. Geol. Oddz. Świętokrzyski.

WIECZOREK D., ZABIELSKI R., STOIŃSKI A. 2020b - Szczegółowa Mapa Geologiczna Polski w skali 1 : 50 000, ark. Przedbórz (775). Aktualizacja. Państw. Inst. Geol. Oddz. Świetokrzyski.

WOHLFARTH B., BJÖRCK S., FUNDER S., HOUMARK-NIELSEN M., INGÓLFSSON Ó., LUNKKA J.-P., MANGERUD J., SAARNISTO M., VORREN T. 2008 - Quaternary of Norden. Episodes 31 (1): 73-81.

WOLNIEWICZ P. 2019 - Bringing the history of the Earth to the public by using storytelling and fossils from decorative stones of the City of Poznań, Poland. Geoheritage, 1: 1827-1837.

WOLNIEWICZ P. 2021 - Beyond Geodiversity Sites: Exploring the Educational Potential of Widespread Geological Features (Rocks, Minerals and Fossils). Geoheritage, 13, https://doi.org/10.1007/s12371-02100557-9

ZWOLIŃSKI Z., NAJWER A., GIARDINO M. - 2018 - Methods for assessing geodiversity. [W:] Reynard E., Brilha J. (red.), Geoheritage: assessment, protection, and management. Elsevier, Amsterdam: 27-52. ŻOŁNIERZ A. 1971 - Kemowe formy w Pasmie Przedborsko-Małogoskim. Roczn. Nauk.-Dydakt. WSP w Krakowie, 40, Pr. Geogr., 5.

Praca wpłynęła do redakcji 14.04.2021 r.

Akceptowano do druku 25.10.2021 r. 
Glazy narzutowe z okolic Przedborza jako obiekty geodziedzictwa oraz ich znaczenie dla geologii czwartorzędu i geoturystyki (patrz str. 34)

Erratic boulders from the Przedbórz Region as objects

important for Quaternary geology and geoheritage (see p. 34)

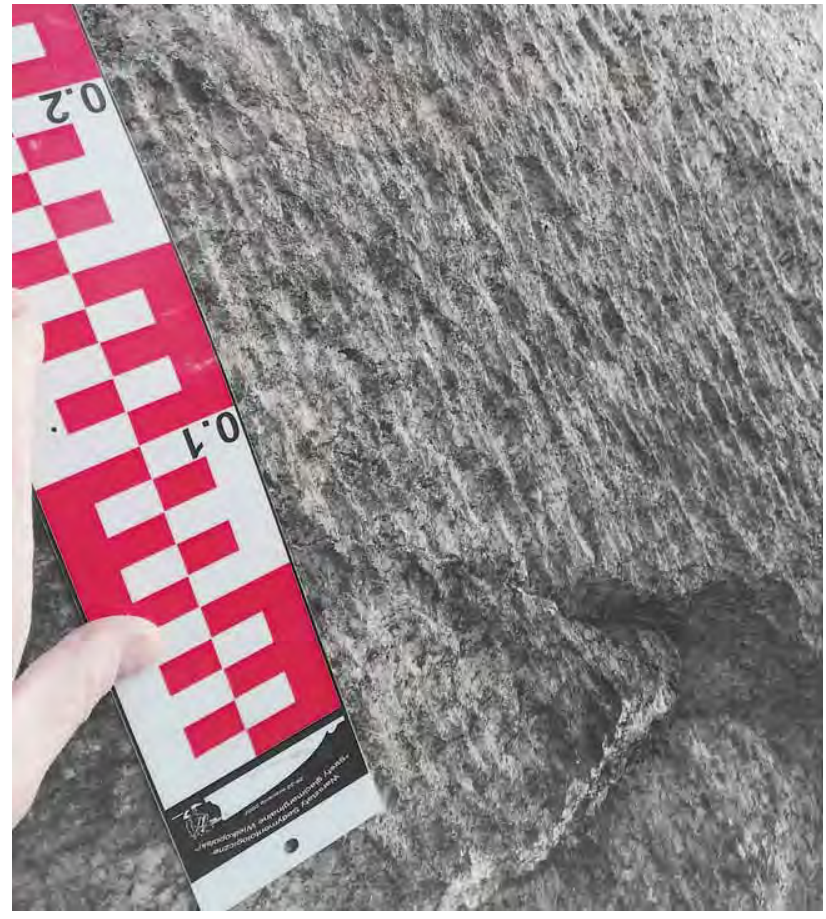

Ryc. 6. Mikrożebra korazyjne na granicie Småland w Wierzbowcu (nr 49 na ryc. 1 - patrz str. 36)

Fig. 6. Corrosive micro-ribs on the Småland granite in Wierzbowiec (No. 49 in Fig. 1 - see p. 36)

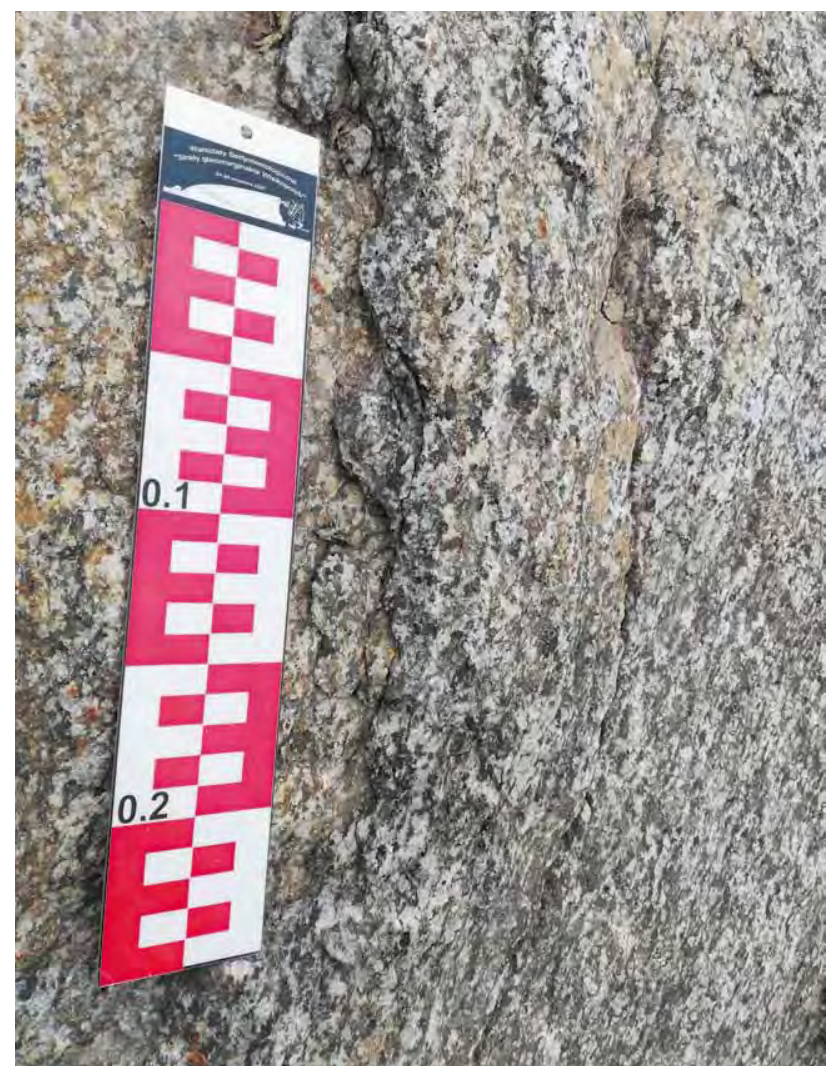

Ryc. 9. Eksfoliacja powierzchni granitu Småland, Kokosia Góra (nr 30 na ryc. 1 - patrz str. 36 )

Fig. 9. Exfoliation on the surface of the Småland granite, Kokosia Góra (No. 30 in Fig. 1 - see p. 36)

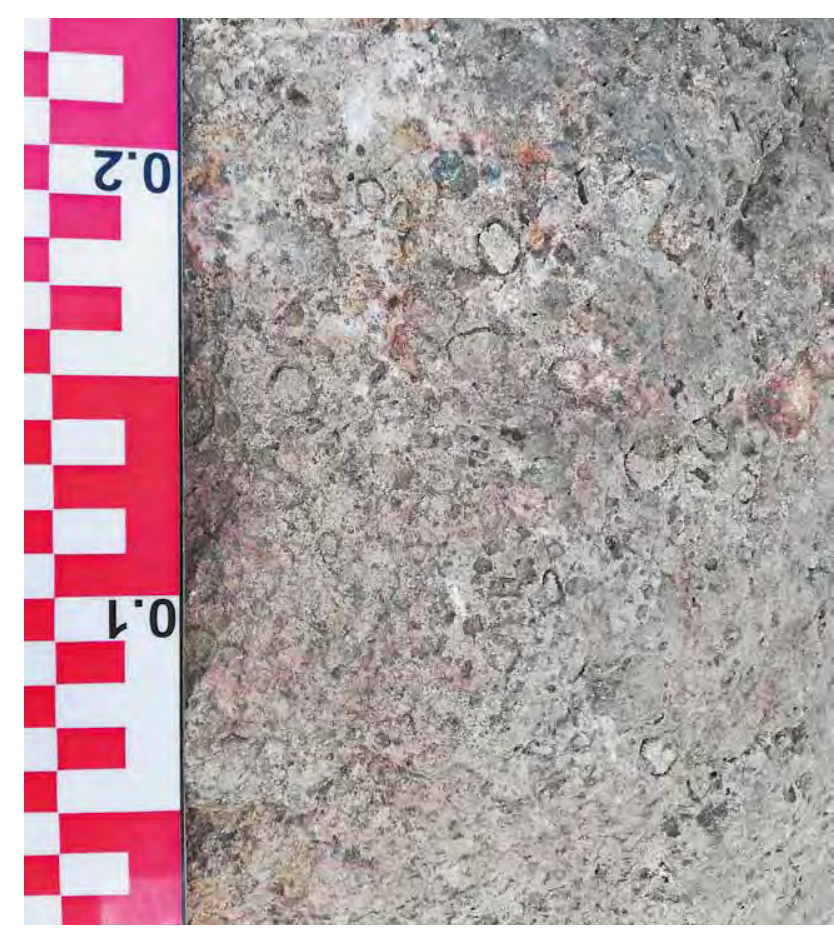

Ryc. 8. Zwietrzałe alandzkie rapakivi w Policzku (nr 70 na ryc. 1 - patrz str. 36)

Fig. 8. Weathered Åland rapakivi in Policzko (No. 70 in Fig. 1 - see p. 36)

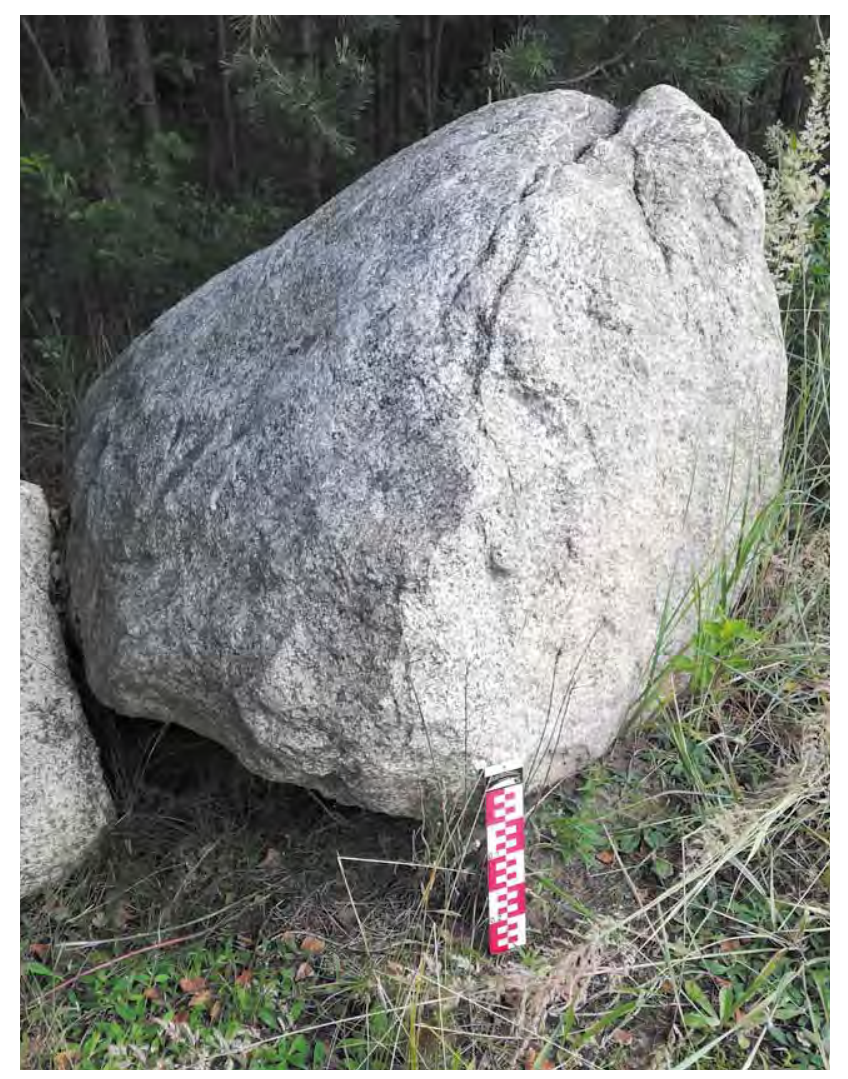

Ryc. 10. Granit z żyłą pegmatytową w Pratkowicach (nr 63 na ryc. 1 - patrz str. 36) - największy głaz narzutowy w okolicach Przedborza Fig. 10. Granite with a pegmatite vein in Pratkowice (No. 63 in Fig. 1 - see p. 36) - the largest erratic boulder near Przedbórz 